\title{
The Effect of Teachers' Unions on Education Production: Evidence from Union Election Certifications in Three Midwestern States
}

\author{
Michael F. Lovenheim, SIEPR, Stanford University
}

Using a unique data set on teachers' union election certifications from Iowa, Indiana, and Minnesota, I estimate the effect of teachers' unions on school district resources and on student educational attainment. My empirical strategy allows for nonparametric leads and lags of union age. I find no impact on teacher pay or per student district expenditures but that unions increase teacher employment by $5 \%$. I find no class size effect because of enrollment increases in unionized districts, and I estimate that unions have no net effect on high school dropout rates. These findings highlight the importance of correctly measuring unionization status.

Public school teacher collective bargaining has become a stable fixture in the American education system over the past 40 years. For example, as of 1988, all but seven states had passed a law either allowing for the right of

I would like to thank John Bound, Jeff Smith, Joel Slemrod, Paul Courant, Raj Chetty, Caroline Hoxby, Patrick Kline, John Pencavel, John Shoven, Gary Solon, Sarah Turner, and Ted St. Antoine for their helpful comments and suggestions, as well as seminar participants at the University of Michigan, the Spencer Foundation Fall Fellows Workshop, Stanford University, the University of Florida, the University of Illinois, the Association for Public Policy Analysis and Management annual meeting, and the American Education Finance Association annual meeting. Collection of the teacher union certification data was funded by a grant from the University of Michigan Public and Nonprofit Management Center. The remainder of this research was generously supported by a Rackham Pre-Doctoral Fellowship, a Spencer Dissertation Fellowship, and the Searle Freedom Trust. All errors,

[Journal of Labor Economics, 2009, vol. 27, no. 4]

(C) 2009 by The University of Chicago. All rights reserved.

0734-306X/2009/2704-0002\$10.00 
teachers to bargain collectively or explicitly requiring districts to bargain with teachers' unions. Furthermore, only four states had statutes prohibiting collective bargaining between public school districts and teachers (Freeman and Valletta 1988). By 2004, 45.1\% of public school teachers were members of a labor union that exists for the purpose of collective bargaining, and $50.8 \%$ were covered by a collective bargaining contract. ${ }^{1}$

Despite, or perhaps because of, the large rise in teacher organization, teachers' unions remain controversial. Opponents of teachers' unions argue that these organizations take reform power away from administrators and parents as well as drain district resources (Haar 1996; Moe 2001). Advocates of teachers' unionization, however, believe that empowering educators who are in the classroom bolsters student achievement by allowing for resources to be distributed in a more effective manner and to be used more efficiently (Retsinas 1982). This debate is particularly relevant today as many reformers push for more competition in primary and secondary schooling. Proponents of increased school competition suggest that introducing more competition into the system will reduce the importance of teachers' unions and partially undo any deleterious impacts these unions may have on districts (Chubb and Moe 1988; Moe 2001). The importance of this argument is reduced if teachers' unionization has no negative effect on school districts or students.

This article analyzes the effect of teachers' unions on the allocation of school district resources as well as on student academic attainment. Historically, a major impediment to conducting this type of research has been the lack of data on which districts have teachers' unions and when they first organized. To remedy this problem, I have hand-collected teachers' union election certification data for all school districts in three midwestern states: Iowa, Indiana, and Minnesota. Because these data are available only in paper format at each state's Public Employment Relations Board office, this information has not been used before in any analysis of teachers' unionization. These data allow me to construct a detailed panel of school districts that contains accurate union representation histories for every district in the sample.

Using data from the 1972-91 Census/Survey of Government (COG/ SOG), I estimate difference-in-difference models with nonparametric leads and lags for union age that allow me to analyze the time pattern of the impact of unions on school district resources. This analytic framework is unique in the teachers' union literature as it requires knowledge of each district's union status in each year covered by the sample. The election certification data I collected contain such information, and I therefore am

omissions, and conclusions are my own. Contact the author at mlovenhe@stanford .edu.

${ }^{1}$ Author's calculation from the May 2004 Current Population Survey. 
able to trace out the time pattern of union effects on school district resources in a manner that puts little structure on this pattern. Furthermore, by examining the pre-election trends, I can determine whether there is any evidence that changes in educational inputs affect union election timing. Previous studies were unable to undertake this type of detailed analysis because of a lack of information on union status in every year covered by the sample.

In contrast to the majority of other studies of the impact of teachers' unions, I find that organization for the purpose of collective bargaining has little effect on educational inputs. Similar to the findings of such studies as Smith (1972), Balfour (1974), Zuelke and Frohreich (1977), and Kleiner and Petree (1988), my results indicate no increase in teacher pay, either in the short run or the long run, due to unionization. ${ }^{2}$ I find that full-time teacher employment increases by about $5 \%$ but that unionization also is associated with an increase in enrollment in union relative to nonunion districts, which offsets any reductions in student-teacher ratios due to the employment increase. While the relative enrollment increases in newly unionized districts could be evidence of selection bias in my estimates, I find little evidence of such bias. My results further indicate that per student current operating expenditures respond negligibly to teachers' unionization.

Finally, I estimate education production functions using the high school dropout rate as the measure of educational output, which is calculated from the 1970-90 U.S. Census. Use of this outcome measure is necessitated by the lack of historical student outcome data at the school district level and should be interpreted as providing suggestive evidence of the link between unionization and educational outcomes. I find that teachers' unions have no discernible net effect on high school dropout rates.

My findings are consistent with those of many of the studies on private sector unions. Freeman and Kleiner (1990) find very modest wage increases among newly unionized firms in the 1980s that they sampled, relative to similar nonunion firms. Dinardo and Lee (2004) estimate the effect of unionization on business survival, employment, output, productivity, and wages using a regression discontinuity framework. Local to the $50 \%$ election vote discontinuity, they find that private sector unions have little effect on these outcome measures. In recent work, Lee and Mas (2008) use an event study analysis to show that private sector unions have a sizable negative effect on excess stock market returns. They also present evidence that this negative effect goes away around the election discon-

\footnotetext{
${ }^{2}$ In his comprehensive review of the literature, Freeman (1986) reports that the majority of teachers' union impact studies find a positive effect of unionization on wages of between $3 \%$ and $21 \%$. He also reports wage premia on the order of $5 \%-10 \%$ for public sector protective services unions.
} 
tinuity of $50 \%$. Interestingly, vote shares in favor of unionization among teachers typically are close to $100 \%$. Given the large institutional differences between public and private sector unions, however, it is difficult to draw too many conclusions from comparisons of results across sectors.

A literature more directly related to my analysis examines the effects of teachers' unions on the inputs to and outputs of education. ${ }^{3}$ The results and conclusions of this article are provocative in that they are at odds with most of these previous studies. Using cross-sectional data on the existence of teacher collective bargaining contracts, Eberts and Stone (1986) estimate that teachers' unions increase district costs by $15 \%$ but that they also increase educational productivity by $3 \%$. In a study that employs teachers' union membership data from the Current Population Survey, Baugh and Stone (1982) find that unions increase teacher pay by between $4 \%$ and $12 \%$. Using similar data, Moore and Raisian (1987) estimate a teachers' union wage premium between $3 \%$ and $6 \%$. In contrast, Kleiner and Petree (1988) find that union membership and the percentage covered by contracts have a negligible effect on wages but have a positive and significant impact on SAT scores and nonwage expenditures per student at the state aggregate level.

In the most comprehensive study of teachers' union impacts to date, Hoxby (1996) constructs a district-level panel from the 1972-92 Census of Governments. This study is an advancement over previous cross-sectional work because it uses school district fixed effects to overcome the endogeneity of union status inherent in such estimates. The study finds the presence of a teachers' union, as indicated by the existence of contracts combined with over 50\% teachers' union membership and the district reporting it engages in collective bargaining, increases average teacher pay by over $5 \%$ and current operating expenditures per student by almost $3 \%$, while decreasing student-teacher ratios by 1.1 . Hoxby also reports evidence that unions increase high school dropout rates.

As a means to understand the differences between the estimates I present in this study and many of the estimates reported in previous empirical studies of teachers' unions, I compare my unionization measure and union impact estimates with those derived from the COG Labor Relations Survey, which is the union measure used most notably in Hoxby (1996). I present suggestive evidence that the results disagree due to nonclassical measurement error in the COG union measure, which points to potential measurement problems with the COG Labor Relations Survey rather than any analytical or coding errors committed by Hoxby (1996) in her careful study. The results of this article underscore the importance of correctly measuring union status in union impact analyses, and I argue that the

\footnotetext{
${ }^{3}$ See Freeman (1986) for an overview of the literature.
} 
election certification data I use are a more reliable measure of union status than those used in previous work.

\section{Theoretical Predictions}

Because no comprehensive theoretical model of public sector union behavior exists, it is not clear a priori how unions will affect either district resources or student achievement. A central purpose of any labor union is to maximize the well-being of its members. In order to accomplish this goal, teachers' unions often advocate for higher wages, fewer hours, and higher benefits for teachers. If these unions are successful in advocating for such changes, then districts might redistribute resources toward teacher pay and away from other areas of expenditure that may be more effective at increasing student achievement. As unions become more entrenched and gain more power over time, such effects could amplify as teachers extract more and more rents from districts. In addition, because unions often make it more difficult for districts to fire teachers and because union contracts typically do not involve performance-based compensation, any increase in teacher pay will not necessarily be correlated with an increase in teacher output. Thus, the marginal returns to teacher pay may fall due to teacher organization. ${ }^{4}$

Even a purely rent-seeking union may have a nonnegative effect on student achievement. Because unions often are focused on improving working conditions as well as pay (Retsinas 1982), teacher organization may lead to smaller class sizes and more satisfied teachers. The increase in workers' job satisfaction due to unionization is referred to as a "union voice" effect, and there is evidence in the private sector literature that giving workers a voice with which to change their working environment increases productivity (Gunderson 2005). If teachers protect themselves from perceived or actual administrative abuses by exercising their union voice, unionization can have positive productivity effects. Additionally, any increase in wages or benefits could attract better teachers, thus increasing average teacher productivity.

In contrast to the rent-seeking model of union behavior, teachers' unions may seek explicitly to maximize student achievement. If there is misallocation of district resources absent unionization, ${ }^{5}$ teachers' unions can use their collective power and their firsthand experience in the classroom to help redistribute resources in a manner that is more effective for education. Similarly, unions may have a positive impact on districts if

${ }^{4}$ This is typically called the "rent-seeking" model of union behavior, as unions seek to extract rents from the district without regard to their impact on students.

${ }^{5}$ Such a misallocation could arise due to the politicization of funding decisions at the local level or from inefficient district management. See Chubb and Moe (1988) for a discussion of these issues. 
they divert more local government funds from other sources to schools. This would result in an increase in the level of funding for schools but not necessarily a change in the distribution.

These predictions of the impact of unionization on school districts and students are not mutually exclusive. Unions might be advocating simultaneously for increases in teacher pay, for better working conditions, and for resources that will more effectively serve students. To the extent that these outcomes have differential effects on achievement, simple models of union behavior do not yield unique predictions about the impact of unionization. It therefore is necessary to analyze empirically the effect that teachers' unions have on students and school districts in order to evaluate the claims made by both advocates and opponents of these unions.

\section{Data}

\section{A. Teachers' Union Election Certification Data}

Studies of the impact of teachers' unions have used two forms of unionization measures, depending on the level of observation in the study. If the study is at the teacher level, the union measure typically is whether the teacher is a member of a union (Baugh and Stone 1982; Moore and Raisian 1987). The largest problem with using union membership data is that teachers can be employed in unionized districts without being members of the union. Furthermore, being a union member does not necessarily mean that the union engages in collective bargaining; many unions in the United States function merely as professional organizations. ${ }^{6}$

Studies that take the school district as the level of observation tend to use the existence of a contract or collective bargaining agreement as the measure of teachers' unionization (Woodbury 1985; Eberts and Stone 1986; Eberts and Stone 1987; Kleiner and Petree 1988; Hoxby 1996). Absent measurement error, a collective bargaining agreement will accurately measure the presence of a union as long as all unions obtain contracts. ${ }^{7}$ According to the NEA and AFT, which represent the vast majority of teachers' unions in the United States, it is rare for a unionized district to never obtain a contract, although there can be a lag between union formation and the culmination of collective bargaining in the form of a contract.

No previous union effects study has been based on data that accurately describe both the timing of unionization and the existence of a teachers'

${ }^{6}$ Both the National Education Association (NEA) and the American Federation of Teachers (AFT) began this way before the official onset of collective bargaining for teachers.

${ }^{7}$ Being unionized is necessary for engaging in collective bargaining, but a union that negotiates with a school district is not guaranteed to obtain a contract. 
union in a given district. In order to obtain an improved measure of teacher unionization, I hand-collected teachers' union certification dates from union election certifications housed in the Public Employment Relations Board (PERB) offices in Iowa, Indiana, and Minnesota. When teachers in a district organize for the purpose of collective bargaining, the state PERB conducts an election. If over $50 \%$ of all school district teachers vote "yes," then the board certifies the union as the sole bargaining representative of the teachers. The date of the election certification is thus the official date of unionization in each district.

To increase the accuracy of my union measure, I supplemented the certification data by searching for case law on LexisNexis as well as on the Indiana Education Employment Relations Board and the Iowa State Teachers' Association Web sites that indicated when a district began collectively bargaining with teachers. If there was a negotiated contract in a district prior to the certification vote, it is likely to be picked up through these searches. Furthermore, because the unions in the three states in this analysis all are members of the NEA, groups of locals are aggregated into "UniServ" districts, which oversee the bargaining and governance of the union locals. I validated the election certification data by contacting the UniServ districts and requesting the date of first contract and the date of first certification for each union local in their district. Many UniServ districts did not have this information, which highlights the difficulty in collecting accurate union data. For the UniServ districts that had this information, I found that the election certification data augmented with the Web searches accurately represented the timing of union formation. In the few cases in which there was a discrepancy, I used the date given by the UniServ office rather than the date recorded from the PERB office. ${ }^{8}$

Iowa, Indiana, and Minnesota are particularly attractive states for this analysis because all three passed "duty-to-bargain" laws in a time period covered by my outcome data. Prior to 1972, all three states allowed collective bargaining between teachers and districts, but a school district did not have a duty to bargain with teachers if the administration did not choose to do so. As a result, there were few contracts in place prior to 1972. ${ }^{9}$ These contracts were all due to "voluntary recognition" of the union by the school district. Beginning in Minnesota in 1972 and followed

${ }^{8}$ If two districts merge, necessitating a new union election, then the election data will assign this merger date as the date of unionization even if both districts were unionized prior to the merger. To each merged district, I assigned a unionization date equal to the earliest unionization date of the original districts. I obtained these dates from the Web searches and UniServ districts, as described above.

${ }^{9}$ The supplemental Web searches and the validation of the election data suggest that I am accurately measuring the existence of contracts in the small number of districts that had teachers' union contracts prior to the passage of their state's dutyto-bargain law. 
by Indiana in 1973 and Iowa in 1975, the states passed duty-to-bargain laws, which mandated that a school district administration is legally bound to bargain in good faith with employees if the employees so desire. These laws dramatically increased unionization rates among teachers in these states (see fig. 1).

Because there was little voluntary recognition of teachers' unions by school districts prior to the passage of the duty-to-bargain laws in these states,$^{10}$ the election certifications measure the time of first organization for the purpose of collective bargaining. ${ }^{11}$ Figure 1 presents the distribution of teachers' union certification years by state. The spikes in the distributions correspond to years in which a state passed a duty-to-bargain law. The small number of districts that were unionized prior to the passage of the state law did so through voluntary recognition by the district administration. As is evident in figure 1, passage of a law establishing teacher collective bargaining was a major determinant of winning a unionization election. ${ }^{12}$ This trend is consistent with those reported by Saltzman (1985), who argues that unionization laws were largely a cause and not an outcome of teacher collective bargaining. The data show that teachers' unions established a significant presence in the public education system over the time period of this analysis in Iowa, Indiana, and Minnesota; all three states had school district teachers' unionization rates of over $75 \%$ by 1987 .

The union certification data have several advantages over the measures used in earlier analyses. The first is that, instead of measuring whether teachers have a contract, which is the outcome of collective bargaining, I measure whether they have an agent certified by the state to engage in collective bargaining. However, the validation study showed that, in the vast majority of cases, unions negotiate a contract within 1 school year of certification, and I found no districts in which the union did not achieve a contract. This result suggests that, while the existence of a union and the existence of a negotiated contract are conceptually distinct, in practice they are similar. Analyzing the effect of winning a unionization election as opposed to negotiating a contract should yield comparable results.

\footnotetext{
${ }^{10}$ When I exclude voluntarily recognized unions from the analysis, the results are unchanged.

${ }^{11}$ In Minnesota, the duty-to-bargain law automatically declared an existing "teachers' council" to have won a certification election if the majority of the council's members belong to one teachers' organization. While it is not entirely clear in the data which of these councils were already engaged in collective bargaining prior to 1972, these districts are marked as being "grandfathered." All results and conclusions are fully robust to dropping these districts from the analysis. Results excluding grandfathered districts are available upon request.

${ }^{12}$ Unlike in the private sector, these elections are rarely unsuccessful. In fact, in my sample, there are no districts in which an election was lost.
} 

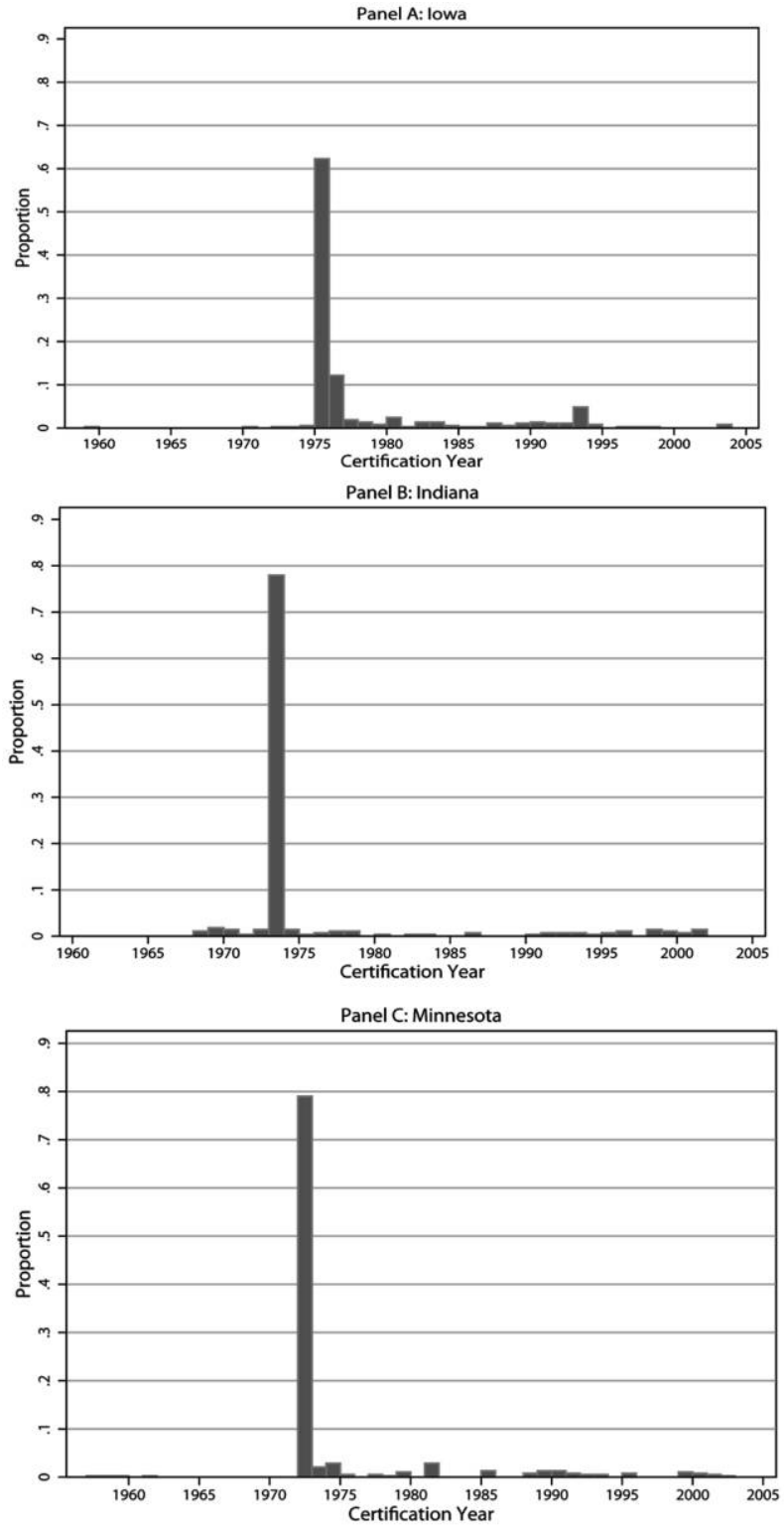

FIG. 1.-Distribution of teachers' union election certifications by state from the teachers' union election certification data described in the text. 
Second, because the certification dates are obtained from official state documents, there will be less measurement error than in data based on survey responses. Finally, the certification measure will not confound the existence of a union whose purpose is collective bargaining with a teachers' organization because purely professional organizations will not engage in a unionization election.

\section{B. Other Data Sources}

I combine my teachers' union election certification data with data from the Census/Survey of Governments (COG/SOG) Employment and Finance Surveys to construct measures of real monthly full-time teacher pay, full-time teacher employment, student-teacher ratios, and real current operating expenditures (COE) per student for each district in the sample. All expenditures are inflated to real 2004 dollars using the CPI-U. I use student-teacher ratios as my measure of class sizes in this analysis, but it is important to note that class size and student-teacher ratios may differ in important ways. In particular, if unions bargain for more preparatory time and more support staff, the student-teacher ratio will be affected but not necessarily the number of students in each classroom. Nevertheless, this is the best measure available in the data, and it measures the prevailing human resources per student in each district. I have district-level observations for the years 1972-91, excluding 1986 due to data availability. Appendix A contains further details about the COG/SOG data.

In addition, I merge the certification data with the 1970, 1980, and 1990 U.S. Census school district summary files ${ }^{13}$ to measure high school dropout rates using the following formula:

$$
\begin{aligned}
& \text { High school dropout rate }= \\
& \left(1-\frac{\text { total high school enrollment }}{\text { total population } 14-18 \text { years old }}\right) \times 100 \text {. }
\end{aligned}
$$

I also calculate total population, percentage urban, average real income, median real gross rent, percentage of families in poverty, percentage unemployed, percentage black, percentage Hispanic, percentage with a high school diploma or some college, percentage with at least a BA, percentage enrolled in private school, and total public school enrollment from these data for each district in my sample.

\footnotetext{
${ }^{13}$ All 1990 Census estimates are from the School District Data Book. The 1980 census data are taken from the 1980 Summary Tape File 3-F (U.S. Department of Commerce 1980), and the 1970 data are taken from the 1970 Census Fourth Count (Population) (U.S. Department of Commerce 1970) and the Census of Population and Housing, 1970: Fifth Count Tallies: Sample Data for School Districts (U.S. Department of Education 1970).
} 


\section{The Effect of Teachers' Unions on Education Production}

A. Trends in School District Resources

Before undertaking an empirical examination of the effect of teachers' unions on school district resources, it is instructive to examine trends in school resources by state and union status in order to inform the empirical methodology. Trends in log real average teacher pay and log real COE per student are presented in figures 2 and 3, respectively, by state and by when districts organized with respect to passage of their state's duty-tobargain law. ${ }^{14}$ Looking at figure 2, across all types of districts there is a general downward trend in teacher pay in the three states. This downward trend is unlikely to be caused by unionization as it begins prior to passage of the duty-to-bargain laws in Indiana and Iowa and continues throughout the sample. ${ }^{15}$ Figure 2 suggests that any empirical model that seeks to identify union effects on teacher pay needs to account for this secular trend. Also, while real teacher pay exhibits some year-to-year noise, the yearly means move very similarly across union and nonunion districts as well as across districts that unionized at different times relative to passage of the duty-to-bargain laws. The means presented in figure 2 thus foreshadow one of the central results of this article, that teachers' unions have no effect on average teacher pay. Figure 3 yields a similar conclusion to that of figure 2; across all school district types within each state, the yearto-year variation in expenditures is virtually identical, and there is little evidence of a break from trend when the duty-to-bargain laws are enacted.

One interpretation of the trends presented in figures 2 and 3 is that threat effects driven by passage of duty-to-bargain laws cause spillovers that affect districts that unionize and districts that do not unionize equally. Because duty-to-bargain laws led to a significant increase in the likelihood of unionization, the potential for union threat effects are particularly relevant in this setting (Farber 2003). ${ }^{16}$ However, teacher pay and current

${ }^{14}$ Trends for log number of teachers, log student-teacher ratios, and log enrollment are shown in appendix figs. B1-B3, respectively. The conclusions drawn from these figures are similar to those from log teacher pay and log COE per student.

${ }^{15}$ While there is an upward spike in teacher pay in 1976 in Iowa, which is the year after passage of the duty-to-bargain law, the same upward spike is exhibited in Indiana and Minnesota and across all school districts, suggesting that it is spurious noise in the data rather than a treatment effect of unionization.

${ }^{16}$ There is considerable debate in the literature over the existence and size of union threat effects. Most of the evidence focuses on private sector unions, where some studies have found unionization raises nonunion wages (Kahn 1980; Neumark and Wachter 1995), reduces nonunion wage dispersion (Kahn and Curme 1987), and increases nonunion benefits (Freeman 1981). However, Farber (2003) finds less concrete evidence of union threat effects on nonunion wages. While there is no evidence in the literature on threat effects of teachers' unions, Ichniowski, Freeman, and Lauer (1989) find that police compensation increases equally among those that 

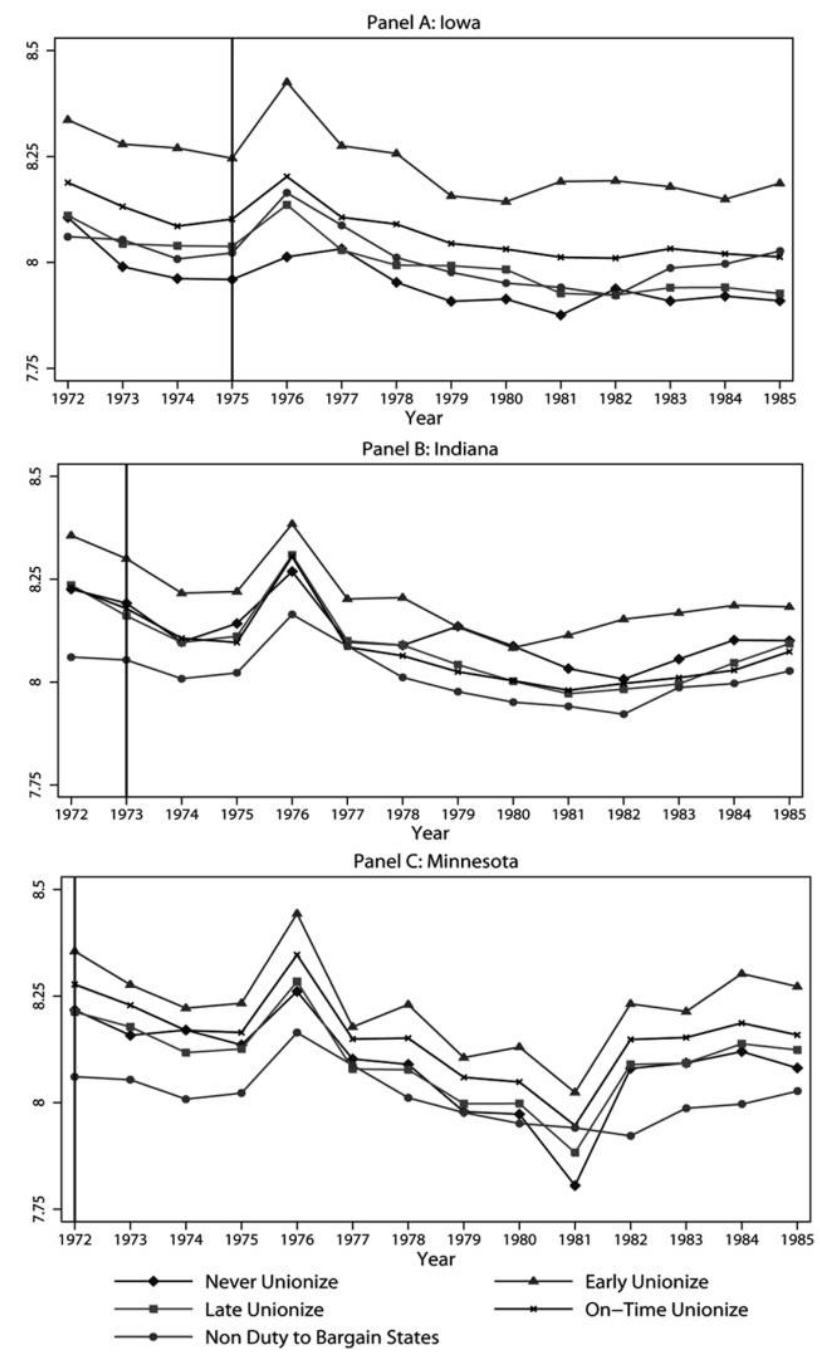

FIG. 2.-Trends in log real average teacher pay by state. The data come from the teachers' union election certification data and Census/Survey of Governments, as described in the text. In each panel, the vertical line represents the year in which a duty-to-bargain law was passed in the state. "Never Unionize" districts are those that do not have a successful union election vote by 2004, "Early Unionize" districts are those that unionize prior to passage of their state's duty-to-bargain law, "Late Unionize" districts are those that unionize more than 1 year after passage of their state's duty-to-bargain law, and "On-Time Unionize" districts are those that unionize within 1 year of passage of their state's duty-to-bargain law. "Non Duty to Bargain States" are the 18 states that did not have a duty-to-bargain law as of 1982: Alabama, Arkansas, Arizona, Colorado, Georgia, Illinois, Kentucky, Louisiana, Missouri, Mississippi, Nebraska, New Mexico, Ohio, South Carolina, Texas, Utah, West Virginia, and Wyoming. All means are inflated to 2004 dollars using the CPI-U. 

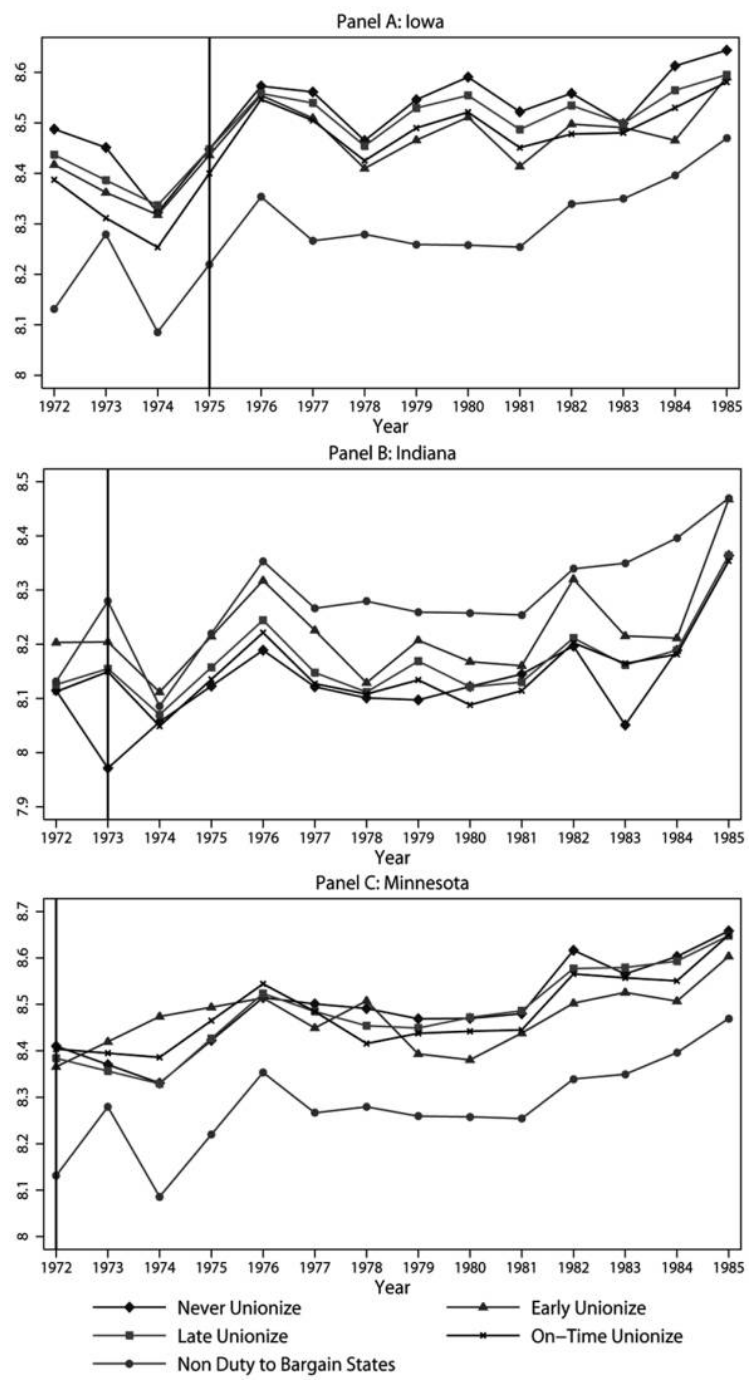

FIG. 3.-Trends in log real current operating expenditures per student by state. The data come from the teachers' union election certification data and Census/Survey of Governments, as described in the text. In each panel, the vertical line represents the year in which a dutyto-bargain law was passed in the state. "Never Unionize" districts are those that do not have a successful union election vote by 2004, "Early Unionize" districts are those that unionize prior to passage of their state's duty-to-bargain law, "Late Unionize" districts are those that unionize more than 1 year after passage of their state's duty-to-bargain law, and "On-Time Unionize" districts are those that unionize within 1 year of passage of their state's duty-tobargain law. "Non Duty to Bargain States" are the 18 states that did not have a duty-tobargain law as of 1982: Alabama, Arkansas, Arizona, Colorado, Georgia, Illinois, Kentucky, Louisiana, Missouri, Mississippi, Nebraska, New Mexico, Ohio, South Carolina, Texas, Utah, West Virginia, and Wyoming. All means are inflated to 2004 dollars using the CPI-U. 
operating expenditures per student do not exhibit breaks from trend surrounding passage of duty-to-bargain laws, and districts that unionized prior to the passage of their state's duty-to-bargain law exhibit year-toyear variation identical to those who never unionize and to those who unionize later. This correlation is unlikely if the driving force behind these trends is threat effects brought about by stronger collective bargaining laws, because the "early unionized" districts already have collectively bargained contracts in place and are unlikely to renegotiate prior to their contracts expiring.

More direct evidence on the relevance of threat effects can be obtained by comparing the trends in figures 2 and 3 to those from the 18 states without duty-to-bargain laws. ${ }^{77}$ Trends for school districts in those states are presented in figures 2 and 3 (as well as in appendix figs. B1-B3). They closely track those in Iowa, Indiana, and Minnesota, which suggests that union threat effects are minimal for these resource measures in the three states covered by this analysis.

Another way to examine the presence of union threat effects is to conduct a cross-state difference-in-difference analysis of school district resources, comparing mean changes in Iowa, Indiana, and Minnesota from before and after passage of the duty-to-bargain laws to changes in states that did not have duty-to-bargain laws and did not pass such a law during this time period. Table 1 presents estimates from such an analysis using the 1972, 1977, and 1982 Census of Governments. The first column in each panel contains state-level means for Iowa, Indiana, and Minnesota, and the second column contains means for the 18 control states. The third column presents difference-in-difference estimates between each year and 1972, and the fourth column shows the standard error of this estimate. The fifth and sixth columns present the results from pooled differencein-difference regressions that use all 3 years.

The cross-state estimates in table 1 show a negative effect of teachers' unions on wages of between $4.0 \%$ and $5.6 \%$, although the estimate is not statistically different from zero when state-specific trends are included in the model. While some of the estimates in panel B suggest that unions significantly decreased teacher employment by over $20 \%$, when I control for state-specific trends, I find no discernible effect. Panel C suggests that unions had a small effect on student-teacher ratios that is not statistically distinguishable from zero in most columns. Finally, in panel D, I find evidence of a negative effect of teachers' unions on per student expenditures. Together, the estimates in table 1 argue against large union threat

unionize and those that do not unionize due to stronger bargaining laws. This is the only evidence on public sector union threat effects in the literature.

${ }^{17}$ These states are Alabama, Arkansas, Arizona, Colorado, Georgia, Illinois, Kentucky, Louisiana, Missouri, Mississippi, Nebraska, New Mexico, Ohio, South Carolina, Texas, Utah, West Virginia, and Wyoming. 
Table 1

Cross-State Difference-in-Difference Estimates of the Effect of Teachers' Unions on School District Resources

\begin{tabular}{|c|c|c|c|c|c|c|}
\hline Year & $\begin{array}{l}\text { Treated } \\
\text { States } \\
(1)\end{array}$ & $\begin{array}{l}\text { Untreated } \\
\text { States } \\
(2)\end{array}$ & $\begin{array}{l}\text { Difference in } \\
\text { Difference } \\
(3)\end{array}$ & $\begin{array}{l}\text { Standard } \\
\text { Error } \\
(4)\end{array}$ & $\begin{array}{c}\text { State } \\
\text { Fixed } \\
\text { Effects } \\
\quad(5)\end{array}$ & $\begin{array}{c}\text { State } \\
\text { Trends } \\
\text { (6) }\end{array}$ \\
\hline & \multicolumn{6}{|c|}{ A. Ln(Real Monthly Full-Time Teacher Pay) } \\
\hline \multirow{4}{*}{$\begin{array}{l}972 \\
977 \\
982\end{array}$} & 8.189 & 8.050 & & & & \\
\hline & 8.074 & 7.983 & $-.048^{* *}$ & $(.017)$ & $-.040 * *$ & -.056 \\
\hline & 8.014 & 7.916 & -.041 & $(.026)$ & $(.015)$ & $(.044)$ \\
\hline & \multicolumn{6}{|c|}{ B. Ln(Full-Time Teacher Employment) } \\
\hline 1972 & 4.164 & 3.461 & & & & \\
\hline 1977 & 4.255 & 3.760 & $-.208 \%$ & $(.043)$ & $-.220 \%$ & .012 \\
\hline \multirow[t]{2}{*}{1982} & 4.171 & 3.871 & $-.403 *$ & $(.091)$ & $(.059)$ & $(.052)$ \\
\hline & \multicolumn{6}{|c|}{ C. Ln(Student-Teacher Ratio) } \\
\hline 1972 & 2.845 & 2.805 & & & & \\
\hline 1977 & 2.717 & 2.662 & .015 & $(.022)$ & $.042^{* * *}$ & -.009 \\
\hline \multirow[t]{2}{*}{1982} & 2.655 & 2.571 & .045 & $(.029)$ & $(.020)$ & $(.022)$ \\
\hline & \multicolumn{6}{|c|}{ D. Ln(Real COE per Student) } \\
\hline 1972 & 8.343 & 8.141 & & & & \\
\hline 1977 & 8.412 & 8.273 & $-.063 * \%$ & $(.030)$ & $-.081 \%$ & -.046 \\
\hline 1982 & 8.459 & 8.345 & $-.088 \% *$ & $(.034)$ & $(.028)$ & $(.052)$ \\
\hline
\end{tabular}

SourcE.-Author's calculation from the 1972, 1977, and 1982 Census of Governments, as described in the text.

NotE.-Col. 1 contains yearly means for Indiana, Iowa, and Minnesota. Col. 2 contains means for the 18 states that did not have a duty-to-bargain law as of 1982: Alabama, Arkansas, Arizona, Colorado, Georgia, Illinois, Kentucky, Louisiana, Missouri, Mississippi, Nebraska, New Mexico, Ohio, South Carolina, Texas, Utah, West Virginia, and Wyoming. Col. 3 contains the difference-in-difference estimates from the first two columns, which are the difference between "treated" and "untreated" in the given year minus the difference between "treated" and "untreated" in 1972. Col. 4 presents the standard errors of these differences, clustered at the state level. Cols. 5 and 6 present difference-in-difference estimates using all 3 years that control for state and year fixed effects in col. 5 and control for state and year fixed effects as well as state-specific linear year trends in col. 6. Standard errors clustered at the state level are in parentheses in cols. 5 and 6.

* Significant at the $5 \%$ level.

effects in Iowa, Indiana, and Minnesota, because in most cases stateaverage resources are moving in the opposite direction than one would predict if unions had a positive effect on teacher pay, teacher employment, and per student expenditures in all school districts in the treated states.

While comparing trends in states that did not enact duty-to-bargain laws to trends in Iowa, Indiana, and Minnesota yields insight into the existence of threat effects and union spillovers, it is difficult to interpret the estimates in table 1 as causal because the 18 control states may experience different secular variation in school resources that will confound identification of the treatment effects of interest. In the absence of union spillovers, a more credible strategy is to use nonunion districts in each state to control for counterfactual trends. The remainder of this article uses such variation to identify union effects on school district resources and on student academic attainment. 


\section{B. The Effect of Teachers' Unions on School District Resource Allocation: Empirical Methodology}

To analyze the effect of teachers' unions on school district resources, I estimate the following equation on the Census/Survey of Governments data described in Section II.A and in appendix A:

$$
Y_{i s t}=\beta_{0}+\sum_{j=-5}^{10} \gamma_{j} I\left(t-\text { year }_{\mathrm{c}}=j\right)+\tau_{i}+\phi_{s t}+\varepsilon_{i s t},
$$

where $Y_{i s t}$ is the log of an outcome variable of interest, $\phi_{s t}$ are state-byyear fixed effects, $\tau_{i}$ are district fixed effects, and $\varepsilon_{i s t}$ is an error term. The term year ${ }_{c}$ refers to the calendar year in which district $i$ became certified, and the expression $I\left(t-\right.$ year $\left._{c}=j\right)$ is an indicator variable that equals one if district $i$ is $j$ years from a unionization election in year $t$ and zero otherwise. For districts that never complete a union election and for observations for which the relative time to unionization is outside the event window, these indicator variables are set to zero. I choose an event window from 5 years prior to 10 year post union election because sample sizes drop outside of this range. All district-year observations for which the time since certification is greater than 10 years are dropped from the analysis.

Due to data limitations, previous studies have modeled union effects by including a dummy variable for union status in their regressions. Equation (2) is more general than using a single union dummy because it semiparametrically estimates both short-term and long-term effects of unionization; ${ }^{18}$ the inclusion of dummy variables for each year relative to unionization imposes no structure on the pattern of time trends either pre- or post-treatment. This flexibility is important because unions may have nonlinear impacts on districts over time that will be masked by imposing the parametric assumption that the effects are equal. ${ }^{19}$ Thus, the full-time pattern of union impacts over the event window allowed by the data will be estimated by equation (2), whereas standard models of union impacts are much more restrictive.

Another major advantage of equation (2) is that it includes district and

${ }^{18}$ The specification is semiparametric because I impose the parametric assumption that the relative time effects and the state-specific year effects are additively separable. This is a standard assumption built into linear regression models.

${ }^{19}$ One might expect the time pattern of union effects to differ over time for several reasons. If unions focus first on gaining a foothold in the district rather than on affecting change, the short-run and long-run union impacts will differ. Unions also may need time to learn how to successfully bargain with administrators. Finally, unions can change the administration in the long run by supporting pro-union candidates for school board and local office. Note also that unions likely affect long-run equilibrium district outcomes past 10 years in a manner that I am unable to capture with my data. 
time fixed effects. This feature contrasts with most of the previous work on union impacts, which has been cross sectional (Freeman 1986). Such a design often is necessitated by the lack of time series data on teacher unionization, but if unionization depends on unobservable factors that are correlated with both the decision to unionize and district outcomes (e.g., a bad administration), cross-sectional estimates will be biased. In contrast, the fixed effects model compares the same district at different times relative to the unionization year and controls for any unobservable (and unchanging) effects.

The central identifying assumption of the model is

$$
E\left(\varepsilon_{i s t} \mid I\left(t-\text { year }_{\mathrm{c}}=j\right) \quad \forall j \in[-5,10], \tau_{i}, \phi_{s t}\right)=0 .
$$

Satisfying (3) necessitates that, conditional on the fixed effects, the timing of unionization is uncorrelated with potential outcomes. If there is selection into unionization based on pre-union wages or expenditures, estimates of the $\gamma_{j}$ parameters from equation (2) will be biased. In addition, if school boards anticipate unionization and enact policies to attempt to defeat the organization movement in the district, it will become apparent in the pre-election relative time to unionization estimates. I therefore estimate $\gamma$ 's prior to the union election $(j<0)$ in order to test for any selection on the outcome variable that may be a causal factor in the decision to hold an election. Rather than controlling for differential pretreatment trends across districts that do and do not unionize, my difference-in-difference setup allows me to test directly for the existence of such trends. Note that, because the Census of Governments panel begins in 1972 and the collective bargaining laws were passed in 1972, 1973, and 1975 in Minnesota, Indiana, and Iowa, respectively, the relative time dummies with $j<0$ will be identified predominantly off of districts that unionize relatively later in the sample. ${ }^{20}$

The Census/Survey of Governments contains no school district demographic information. Given this limitation, it is important to think about why school districts unionized when they did. I investigate this

\footnotetext{
${ }^{20}$ Because the school district panel is unbalanced with respect to relative time to unionization, each $\gamma_{j}$ is identified off of a potentially different set of school districts. See appendix table B1 for the number of observations and the distribution of districts across states that identify each relative year effect. The unbalanced nature of the panel will cause the estimates to be biased if there are unobserved (or unmodeled) heterogeneous treatment effects. To test for this source of bias, I estimate eq. (2) separately for those districts that unionize within 1 year of their state's passage of the duty-to-bargain law. Results are qualitatively and quantitatively similar to those presented below, which is not surprising given that over $84 \%$ of treated observations fall into this group. I also estimate eq. (2) using a balanced panel of school districts that I observe in every survey year. These results are presented in appendix table B2 and are similar to results from using the unbalanced panel, although the standard errors become larger due to sample size reductions.
} 
question by comparing means of observable district demographic characteristics by district unionization status and timing using the 1980 U.S. Census data described in Section II. Columns A and B of table 2 compare districts that never unionize to districts that do unionize as of 2004. The table indicates that districts that never unionize have more high school graduates, have fewer high school dropouts, are less urban, have a lower private school enrollment rate, are smaller, and have a higher poverty rate but lower median rent than districts that unionize. Columns $\mathrm{D}$ and $\mathrm{E}$ in table 2 compare districts that unionized within a year of the passage of their state's duty-to-bargain law and those that unionized later. The comparison of means suggests that districts that unionized immediately following passage of their state's duty-to-bargain law had a larger percentage of adults with a bachelor's degree; were larger; were more urban; had a higher median rent, unemployment rate, and district enrollment; but had a lower poverty rate than those that unionized later. Overall, this exercise suggests that districts in larger cities and suburbs organized earlier, while the more rural districts unionized later or not at all. ${ }^{21}$

What effect can one expect these differences to have on the estimates from equation (2) given that the parameter of interest in this study is the average treatment effect on the treated (ATT) ?22 Note that selection into unionization based on perceived or actual gains from organizing will not bias identification of the ATT; such selection only will bias identification of the average treatment effect. Because the district fixed effects control for any time-invariant differences in outcome levels among the school districts, what is needed to identify the ATT is for the state-specific year effects to accurately reflect the counterfactual trends in the dependent variables for the treated observations. Correctly identifying $\phi_{s t}$ is therefore

${ }^{21}$ There are many explanations for this trend in the literature on the history of teachers' unions. First, administrative abuses were most severe in the larger and more urban districts, therefore inducing a union vote. Second, the urban districts tended to be more industrialized and to have a higher fraction of the populace with union membership. These populations may have been more favorable to teachers' unions, thereby increasing the returns to unionizing. Finally, there are historical reasons that the NEA and AFT were focused on the cities: the NEA started project URBAN in 1968 specifically to target city school districts as a response to AFT successes there. See Murphy (1990) for a detailed history of teacher organization.

${ }^{22}$ Most of the differences between the districts that never unionize, the districts that unionize early, and the districts that unionize later are due to the urban/rural distinction. When I drop all districts that have census blocks in urban areas, the panel becomes much more balanced with respect to the observables in table 2 . Results from estimation of eq. (2) with this sample are presented in appendix table B3, which shows that the union impact estimates do not change appreciably, nor do the substantive conclusions from those estimates change, when this restriction is imposed. 


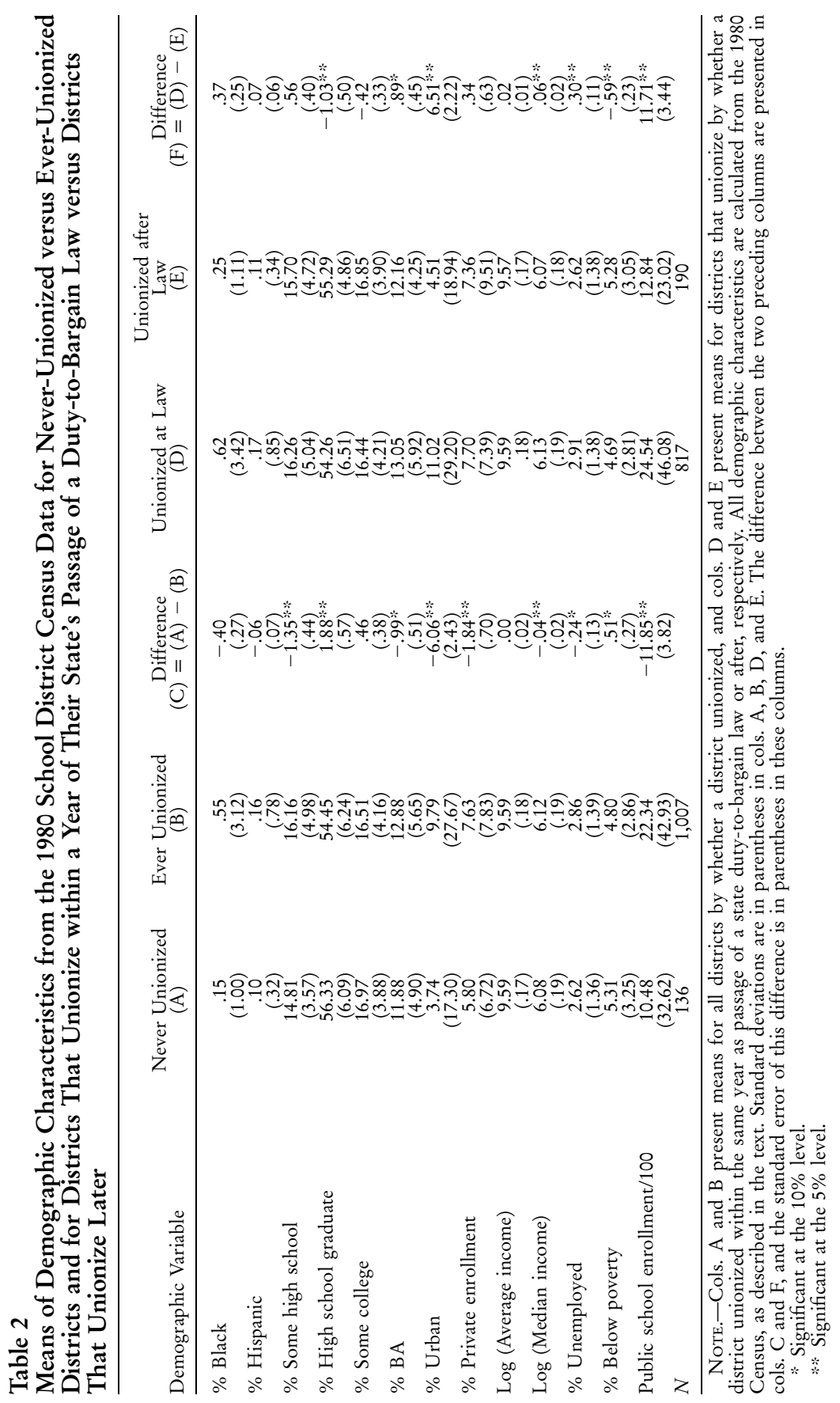


the main difficulty in estimating the treatment effect on the treated using equation (2).

The state-specific year effects are identified off state-specific yearly variation in the dependent variable from the control group (i.e., nontreated observations). In the main results presented in Section III.C.1, I estimate equation (2) using all districts that never unionize combined with all district-year observations for which the relative time to union election is less than or equal to 10. The control group in this sample is composed of never-unionized districts and those district-year observations for which the relative time to unionization is less than -5 . This sample is attractive because it uses all observations that arguably are unaffected by the treatment, which allows for the most power in identifying all parameters of equation (2). In Section III.C.2, I show a series of robustness checks that illustrate that my estimates are not particularly sensitive to the control group used.

\section{The Effect of Teachers' Unions on School District Resource Allocation: Results}

\section{Baseline Results}

Figures 4-7 depict the estimates of $\gamma_{j}$ from equation (2) for log real monthly full-time teacher pay, log full-time teacher employment, log student-teacher ratios, and log real current operating expenditures per student, respectively. In each figure, the points represent the estimates of the $\gamma$ coefficients from each relative-year-to-union-election dummy variable, and the height of the bars extending from each point represent the bounds of the $95 \%$ confidence interval calculated from the standard errors that are clustered at the school district level. ${ }^{23}$ Full regression estimates for the results in figures 4-7 are reported in appendix table B1.

As predicted by the trends in figures 2 and 3, the results consistently indicate that unions have little impact on school district resource levels. Focusing on figure 4, there is no evidence that teachers' unions increase teacher pay; ${ }^{24}$ none of the point estimates are statistically distinguishable from zero at the $5 \%$ level, and most are less than $2 \%$ in magnitude. There also are no evident pre-election trends or anticipation effects that suggest that there is selection in union election timing based on teacher pay trends.

${ }^{23}$ For ease of interpretation, I drop the relative time indicator variable for $j=$ -1 (the year prior to unionization) throughout this analysis. The $\gamma_{j}$ coefficients therefore identify treatment effects relative to the effect for the year prior to unionization, $\gamma_{-1}$. Note that in figs. $4-8 \mathrm{I}$ include a zero for the point estimates in relative year $j=-1$, but the lack of standard error bars reflects that this zero is imposed rather than estimated.

${ }^{24}$ It is important to note these are average wages. Unions may change the wage structure within districts without shifting the mean. 


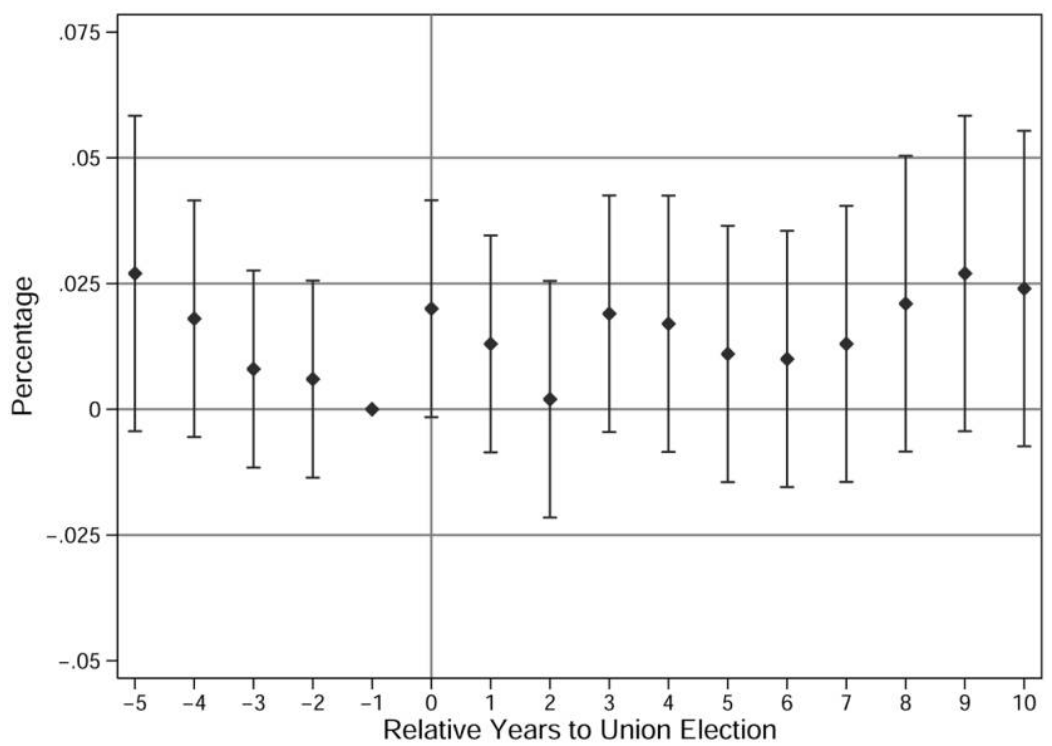

FIG. 4.-The effect of teachers' unions on log real monthly full-time teacher pay. The points represent coefficient estimates from estimation of eq. (2) on the 1972-91 Census/Survey of Governments data, as described in the text. The bars extending from each point show the bounds of the $95 \%$ confidence interval calculated from standard errors that are clustered at the district level. Relative year -1 is omitted in order to make all estimates relative to the year prior to unionization. I include a zero for the point estimate in relative year $j=-1$, but lack of standard error bars reflect that this zero is imposed rather than estimated.

These results are at odds with the vast majority of teachers' union impact studies that find a positive union wage premium (see Freeman [1986] for an overview). Hoxby's (1996) estimate of $5.1 \%$ is also outside the $95 \%$ confidence interval estimated here for all but the last 2 years of the event window. Second, although there is evidence in the literature that the union wage premium increased substantially over the 1970s (Baugh and Stone 1982; Freeman 1986), no such increase appears in figure $4 .^{25}$ Over time, as the union position became more solidified in these school districts, there is no statistically significant evidence that they achieved wage gains for their members.

Results for full-time teacher employment are shown in figure 5. They suggest that employment increases immediately following unionization by close to $5 \%$ and remains at this level over time. The majority of the

${ }^{25}$ The explanation commonly given for this increase is that, in the earlier years of the teacher unionization movement, unions were focused on gaining a foothold in the district rather than on wage gains. As unions became more accepted over the course of the 1970s, they turned their attention to obtaining wage increases for their constituents. 


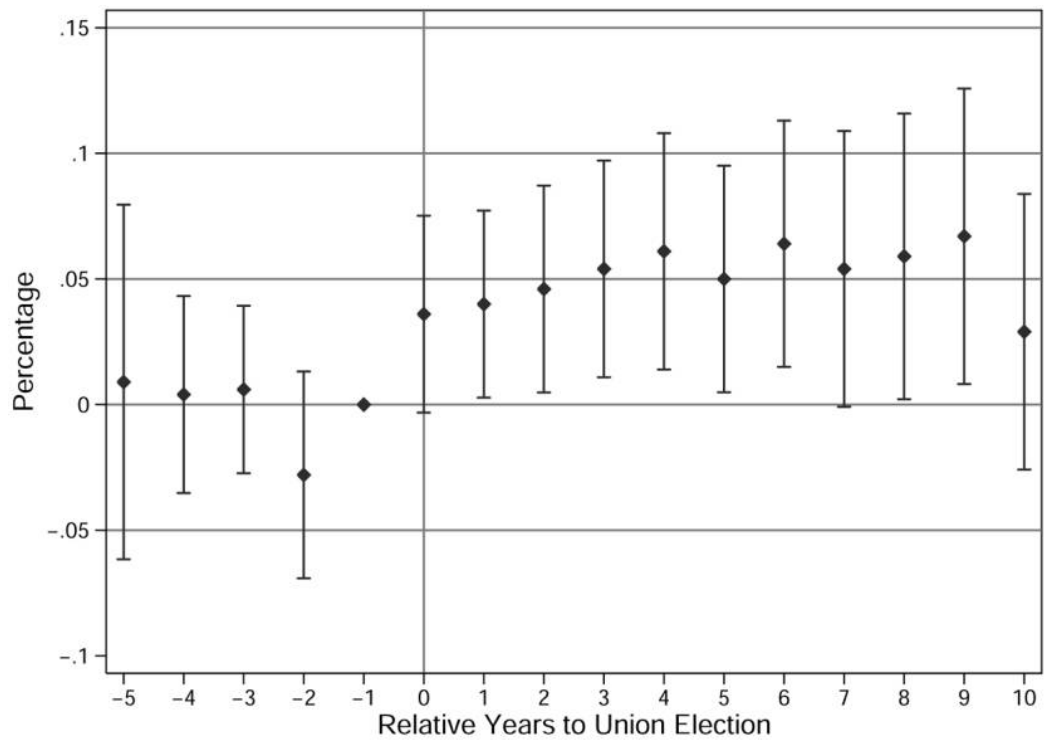

FIG. 5.-The effect of teachers' unions on log full-time teacher employment. The points represent coefficient estimates from estimation of eq. (2) on the 1972-91 Census/Survey of Governments data, as described in the text. The bars extending from each point show the bounds of the $95 \%$ confidence interval calculated from standard errors that are clustered at the district level. Relative year -1 is omitted in order to make all estimates relative to the year prior to unionization. I include a zero for the point estimate in relative year $j=-1$, but lack of standard error bars reflect that this zero is imposed rather than estimated.

post-election estimates are statistically distinguishable from zero at the $5 \%$ level. These results are consistent with a model of union behavior in which teachers bargain over class size, preparatory time, and noninstructional supervision responsibilities, causing more teachers to be hired. ${ }^{26}$

Despite the increase in teacher employment, figure 6 illustrates that winning a unionization election has little effect on student-teacher ratios; while all point estimates for $j>0$ are negative, none are statistically significant. The explanation for the seemingly contradictory results in figures 5 and 6 is that student enrollment increases after unionization. I estimated equation (2) using log student enrollment as the dependent variable; these results are presented in figure 8. I find that enrollment is unaffected in the first 2 years following unionization but that it then increases to about $5 \%$ over the next 3 years and remains at this level for the remainder of the event window. Thus, teacher employment increases immediately upon unionization, but within 4 years after certification, enrollment expansion

${ }^{26}$ Figure 5 also could be evidence of a principal-agent model in which the union representatives seek to maximize union dues by forcing the district to hire more teachers. 


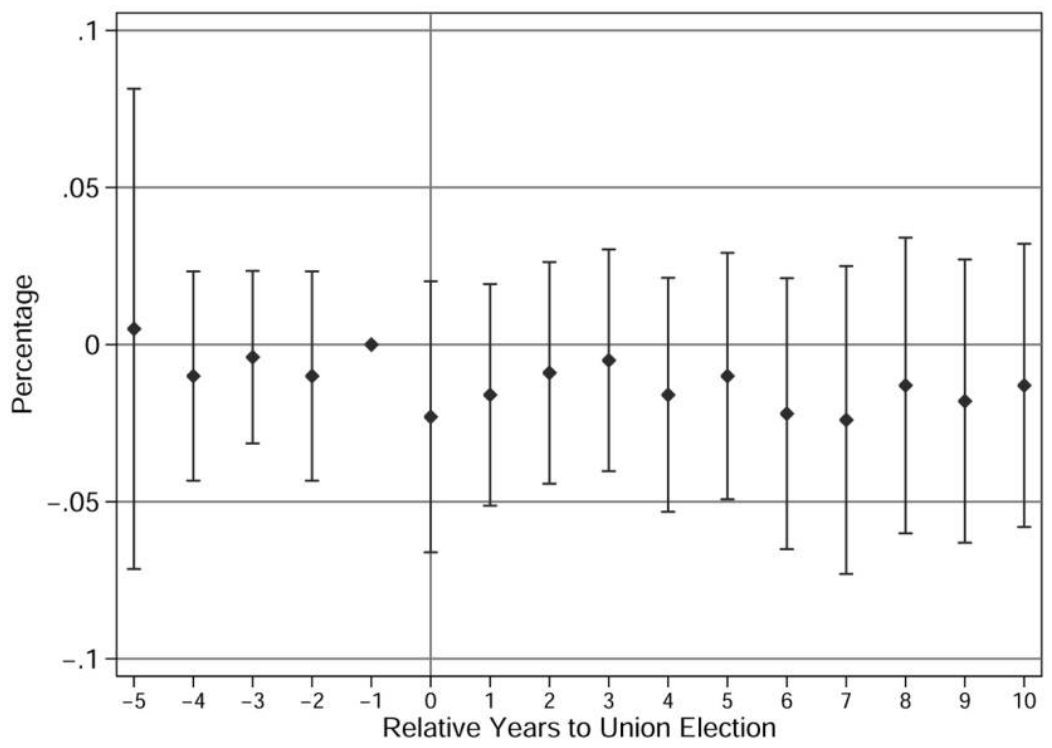

FIG. 6.-The effect of teachers' unions on log student-teacher ratios. The points represent coefficient estimates from estimation of eq. (2) on the 1972-91 Census/Survey of Governments data, as described in the text. The bars extending from each point show the bounds of the 95\% confidence interval calculated from standard errors that are clustered at the district level. Relative year -1 is omitted in order to make all estimates relative to the year prior to unionization. I include a zero for the point estimate in relative year $j=-1$, but lack of standard error bars reflect that this zero is imposed rather than estimated.

in treated districts, relative to control districts, undoes the decline in class sizes that would occur from increased teacher employment. ${ }^{27}$ Importantly, there is little evidence of relative pre-unionization trends in figure 8, which suggests that this result is not being driven by selection into unionization based on recent enrollment patterns.

Unlike private sector unions, public sector unions can try to influence the total amount of resources available as well as their share of resources (Courant, Gramlich, and Rubinfeld 1979; Freeman 1986); through political lobbying and public relations, teachers' unions can increase the provision of public education. ${ }^{28}$ Figure 7 examines this possibility by analyzing the effect of teachers' unions on log real COE per student. There

${ }^{27}$ Note that most districts in the three states are losing population over this time period. The enrollment change is due to slower net out-migration rather than faster net in-migration in unionized districts relative to nonunion districts (see fig. B3).

${ }^{28}$ Interestingly, this is one area where the administration and the teachers' union might agree. One explanation for the acquiescence of school boards to teachers' unionization might be that the administration hopes to increase provision of public education through the union's political actions. 


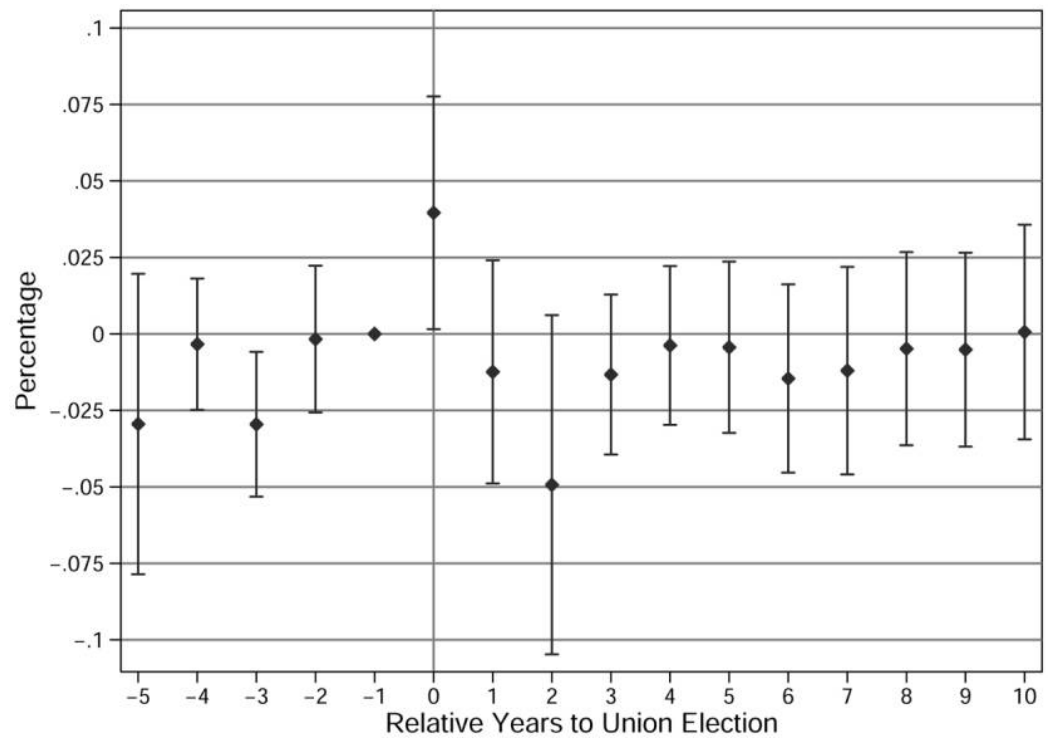

FIG. 7.-The effect of teachers' unions on log real current operating expenditures per student. The points represent coefficient estimates from estimation of eq. (2) on the 1972-91 Census/ Survey of Governments data, as described in the text. The bars extending from each point show the bounds of the $95 \%$ confidence interval calculated from standard errors that are clustered at the district level. Relative year -1 is omitted in order to make all estimates relative to the year prior to unionization. I include a zero for the point estimate in relative year $j=$ -1 , but lack of standard error bars reflect that this zero is imposed rather than estimated.

is considerable variation in the estimates: the first year post-unionization shows a positive and significant spike in COE per student of about $4 \%$, after which the estimates become negative and remain close to zero for the remainder of the event window. Furthermore, figure 7 shows some variation in relative pre-treatment trends, but examination of figure 3 suggests that these differences are more likely due to noise in the data than that they indicate selection on relative trends in per student current operating expenditures. Note that this figure represents changes in per student expenditures. As enrollment is increasing by about $5 \%$ over this period in unionized districts relative to control districts, total expenditures do increase, though not enough to keep up with the enrollment increases. One interpretation of figure 7 is that teachers' unions successfully guard against per student expenditure losses in the face of rising relative enrollment. However, an equally plausible interpretation is that unions have little effect, especially in the long run, on this outcome.

\section{Robustness Checks}

As discussed in Section III.B, the critical assumption underlying identification of the $\gamma$ coefficients in equation (2) is the use of an appropriate 


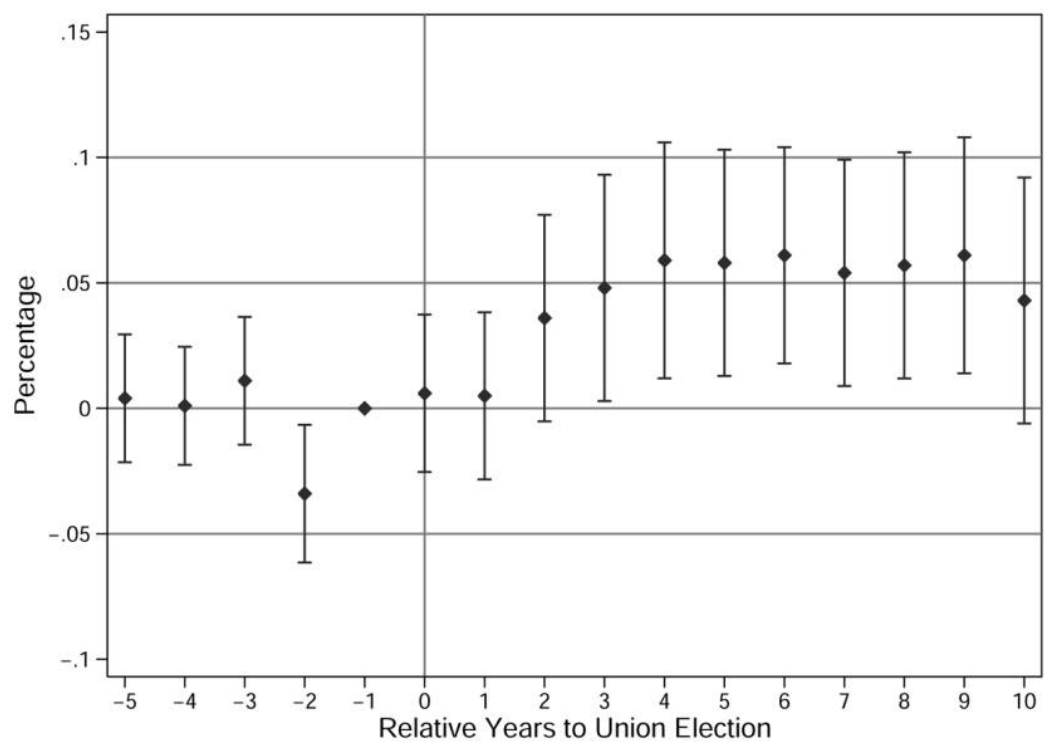

FIG. 8.-The effect of teachers' unions on log student enrollment. The points represent coefficient estimates from estimation of eq. (2) on the 1972-1991 Census/Survey of Governments data, as described in the text. The bars extending from each point show the bounds of the $95 \%$ confidence interval calculated from standard errors that are clustered at the district level. Relative year -1 is omitted in order to make all estimates relative to the year prior to unionization. I include a zero for the point estimate in relative year $j=-1$, but lack of standard error bars reflect that this zero is imposed rather than estimated.

control group to account for secular variation in school district resources. Recall that figures 2 and 3, as well as figures B1-B3, suggest that my estimates should not be particularly sensitive to the within-state nonunion districts I use as a control group because yearly trends are very similar across districts that unionized at different times and across districts that never unionized and those that did. Nonetheless, I assess the fragility of my results to the choice of estimation sample by estimating equation (2) using additional samples that each imply a different control group. First, I restrict the estimation sample to include only never-unionized districts and the district-year observations for which the relative time to certification falls within the event window. The control group implied by this estimation sample is composed of only the never-unionized districts and is attractive relative to the control group used to generate the main estimates because the proportion of districts that do unionize and never unionize is not changing over time. Furthermore, this control group will be unaffected by union effects on the dependent variable more than 5 years prior to unionization. I also obtain estimates using only those district-year observations for which the relative time to unionization is less 
than or equal to 10. This sample is the same as the one used to estimate the parameters shown in figures $4-8$, but it excludes never-unionized districts. The implied control group is thus the district-year observations for which the relative time to certification is less than -5 .

In order to summarize these estimates, I estimate regressions on each sample that include a linear term for relative union age (including negative ages), which is set to zero for never-unionized districts, a union status dummy variable equal to one if the district is unionized in a given year, and an interaction between union status and years relative to unionization. This model is a form of equation (2) in which I constrain the relative preand post-unionization trends to be linear. ${ }^{29}$ As expected, estimates from these robustness checks are very similar in both magnitude and quality to those presented in Section III.C. 1 and are shown in table 3.

Another way to identify union effects is to control directly for pretreatment trends of districts that unionize. ${ }^{30}$ Results from such a model are presented in table 4, in which the analysis sample is all district-year observations with relative years to union election less than 11. I control for both year and district fixed effects as well as a linear measure of relative union age. Due to the exclusion of districts that do not unionize and of district-year observations with union ages greater than 10 years, the linear union age coefficient controls for pre-union trends in outcomes among districts that will unionize in the future. These estimates should be unaffected by union threat effects, but they will not be consistent for the ATT if there are secular trends in the dependent variable that are spuriously correlated with union timing.

The results are consistent in both magnitude and statistical significance to those presented in figures 4-8. In particular, I find little evidence of a union effect on teachers' wages and student-teacher ratios in the short run or the long run. While the estimated effects on teacher employment are somewhat smaller than the estimates in figure 5, they are positive and qualitatively similar. The estimates for current operating expenditures per student are consistent with those in figure 7 directly after unionization, but they suggest a potential negative longer-run effect. Finally, table 4 shows a similar enrollment effect to the estimates in figure 8 . The similarity of these results to those reported in Section III.C.1 suggests that union threat effects are not biasing my identification of the effect of teachers' unions on school district resources and that unions have little effect on school district resource allocation. However, if unions influence teacher

${ }^{29}$ Estimates of the $\gamma$ coefficients, estimated using eq. (2) on these samples, are available from the author upon request.

${ }^{30}$ Note that controlling for pre-treatment trends of districts that unionized is akin to a first-difference model, rather than the difference-in-difference model given by eq. (2). 
Table 3

Fixed Effects Estimates of Teachers' Union Impacts on Resource Levels from the Census/Survey of Governments Using Different Control Groups

\begin{tabular}{|c|c|c|c|c|c|}
\hline \multirow[b]{2}{*}{$\begin{array}{l}\text { Dependent } \\
\text { Variable }\end{array}$} & \multicolumn{5}{|c|}{ Dependent Variable: Log of } \\
\hline & $\begin{array}{c}\text { Real } \\
\text { Full-Time } \\
\text { Teacher Pay }\end{array}$ & $\begin{array}{l}\text { Full-Time } \\
\text { Teacher } \\
\text { Employment }\end{array}$ & $\begin{array}{l}\text { Student- } \\
\text { Teacher } \\
\text { Ratio }\end{array}$ & $\begin{array}{c}\text { Real } \\
\text { COE per } \\
\text { Student }\end{array}$ & $\begin{array}{c}\text { Total } \\
\text { Enrollment }\end{array}$ \\
\hline & \multicolumn{5}{|c|}{ A. Results Using Never-Unionized Districts as Control Group } \\
\hline $\begin{array}{l}\text { Years relative to } \\
\text { unionization } \\
\text { Union }\end{array}$ & $\begin{array}{c}-.003 \\
(.005) \\
.013 \\
(.014)\end{array}$ & $\begin{array}{l}.001 \\
(.009) \\
.051^{* * *} \\
(.025)\end{array}$ & $\begin{array}{c}-.001 \\
(.010) \\
-.012 \\
(.002)\end{array}$ & $\begin{array}{c}.005 \\
(.006) \\
-.002 \\
(.014)\end{array}$ & $\begin{array}{l}.000 \\
(.004) \\
.032^{* *} \\
(.016)\end{array}$ \\
\hline \multirow[t]{2}{*}{$\begin{array}{l}\text { Union } \times \text { Years } \\
\text { relative to } \\
\text { unionization }\end{array}$} & $\begin{array}{l}.005 \\
(.005)\end{array}$ & $\begin{array}{c}-.001 \\
(.009)\end{array}$ & $\begin{array}{l}-.022 * * \\
(.010)\end{array}$ & $\begin{array}{c}-.007 \\
(.007)\end{array}$ & $\begin{array}{l}.005 \\
(.005)\end{array}$ \\
\hline & \multicolumn{5}{|c|}{ B. Results Using Late Unionized Districts as Control Group } \\
\hline $\begin{array}{l}\text { Years relative to } \\
\text { unionization } \\
\text { Union }\end{array}$ & $\begin{array}{c}-.005 * * \\
(.002) \\
.005 \\
(.008)\end{array}$ & $\begin{array}{l}-.002 \\
(.004) \\
.044 * * \\
(.018)\end{array}$ & $\begin{array}{c}-.026 * * \\
(.002) \\
-.011 \\
(.017)\end{array}$ & $\begin{array}{l}.030 * \% \\
(.008) \\
.005 \\
(.012)\end{array}$ & $\begin{array}{c}-.017 * * \\
(.003) \\
.022 \\
(.018)\end{array}$ \\
\hline $\begin{array}{l}\text { Union } \times \text { Years } \\
\text { relative to } \\
\text { unionization }\end{array}$ & $\begin{array}{l}.001 \\
(.001)\end{array}$ & $\begin{array}{c}-.001 \\
(.002)\end{array}$ & $\begin{array}{c}.002 \\
(.002)\end{array}$ & $\begin{array}{c}-.001 \\
(.002)\end{array}$ & $\begin{array}{l}.004 * \\
(.002)\end{array}$ \\
\hline
\end{tabular}

Note.-The analysis sample in panel A includes only district-year observations with time to unionization less than or equal to 10 years and greater than -6 years, as well as never-unionized districts. The analysis sample in panel B includes only district-year observations with time to unionization less than or equal to 10 years, excluding never-unionized districts. The implicit control group in the panel B regressions are district-year observations that unionize more than 5 years in the future in any calendar year. Regressions include school district- and state-specific year fixed effects. The variable years relative to unionization is the number of years relative to election certification, which includes negative values for the 5 years prior to certification. For districts that do not unionize and for district-year observations that unionize more than 5 years in the future, years relative to unionization is set to zero. The variable union is a dummy variable equal to one if a district has successfully unionized as of that calendar year. All standard errors are clustered at the school district level and are shown in parentheses.

* Significant at the $10 \%$ level.

** Significant at the $5 \%$ level.

productivity, they still can affect student achievement. I next turn to an empirical analysis of the effect of unions on high school dropout rates to test for such effects.

\section{The Effect of Teachers' Unions on High School Dropout Rates}

In order to test whether teachers' unions affect educational attainment among students, I estimate linear education production functions using high school dropout rates as my outcome measure. This analysis therefore will be focused on those at the lower end of the educational attainment distribution. Because the high school dropout rate is calculated from 1970, 1980, and 1990 school district-level U.S. Census data (see Sec. II.B), I 
Table 4

Fixed Effects Estimates of Teachers' Union Impacts on Resource Levels from the Census/Survey of Governments Controlling for Pre-Treatment Trends

\begin{tabular}{|c|c|c|c|c|c|}
\hline \multirow[b]{2}{*}{$\begin{array}{l}\text { Dependent } \\
\text { Variable }\end{array}$} & \multicolumn{5}{|c|}{ Dependent Variable: Log of } \\
\hline & $\begin{array}{c}\text { Real } \\
\text { Full-Time } \\
\text { Teacher Pay }\end{array}$ & $\begin{array}{l}\text { Full-Time } \\
\text { Teacher } \\
\text { Employment }\end{array}$ & $\begin{array}{l}\text { Student- } \\
\text { Teacher } \\
\text { Ratio }\end{array}$ & $\begin{array}{l}\text { Real } \\
\text { COE per } \\
\text { Student }\end{array}$ & $\begin{array}{l}\text { Total } \\
\text { Enrollment }\end{array}$ \\
\hline \multicolumn{6}{|l|}{ Years relative to } \\
\hline unionization & $\begin{array}{c}-.004 * \% \\
(.001)\end{array}$ & $\begin{array}{l}.008^{* * \%} \\
(.003)\end{array}$ & $\begin{array}{c}-.022 * * \\
(.002)\end{array}$ & $\begin{array}{l}.022 * \% \\
(.001)\end{array}$ & $\begin{array}{c}-.015^{* *} \\
(.002)\end{array}$ \\
\hline \multicolumn{6}{|l|}{ Union age: } \\
\hline 0 years & $\begin{array}{c}.005 \\
(.017)\end{array}$ & $\begin{array}{c}.016 \\
(.012)\end{array}$ & $\begin{array}{c}-.013 \\
(.010)\end{array}$ & $\begin{array}{l}.037 * * \\
(.013)\end{array}$ & $\begin{array}{c}-.003 \\
(.011)\end{array}$ \\
\hline 1 year & $\begin{array}{l}.002 \\
(.008)\end{array}$ & $\begin{array}{l}.017 \\
(.014)\end{array}$ & $\begin{array}{c}-.014 \\
(.011)\end{array}$ & $\begin{array}{c}.018 \\
(.015)\end{array}$ & $\begin{array}{c}-.003 \\
(.012)\end{array}$ \\
\hline 2 years & $\begin{array}{l}.007 \\
(.010)\end{array}$ & $\begin{array}{l}.012 \\
(.017)\end{array}$ & $\begin{array}{c}-.018 \\
(.014)\end{array}$ & $\begin{array}{c}-.014 \\
(.032)\end{array}$ & $\begin{array}{l}.015 \\
(.017)\end{array}$ \\
\hline 3 years & $\begin{array}{l}.023 \% * \\
(.011)\end{array}$ & $\begin{array}{c}.017 \\
(.019)\end{array}$ & $\begin{array}{c}.001 \\
(.014)\end{array}$ & $\begin{array}{c}-.004 \\
(.013)\end{array}$ & $\begin{array}{c}.015 \\
(.019)\end{array}$ \\
\hline 4 years & $\begin{array}{l}.000 \\
(.012)\end{array}$ & $\begin{array}{l}.023 \\
(.021)\end{array}$ & $\begin{array}{l}.000 \\
(.014)\end{array}$ & $\begin{array}{c}-.002 \\
(.013)\end{array}$ & $\begin{array}{l}.024 \\
(.020)\end{array}$ \\
\hline 5 years & $\begin{array}{c}-.012 \\
(.012)\end{array}$ & $\begin{array}{l}.030 \\
(.022)\end{array}$ & $\begin{array}{c}-.015 \\
(.016)\end{array}$ & $\begin{array}{c}-.003 \\
(.014)\end{array}$ & $\begin{array}{l}.030 \\
(.021)\end{array}$ \\
\hline 6 years & $\begin{array}{l}.000 \\
(.013)\end{array}$ & $\begin{array}{l}.020 \\
(.024)\end{array}$ & $\begin{array}{c}-.004 \\
(.017)\end{array}$ & $\begin{array}{c}-.033^{* *} \\
(.015)\end{array}$ & $\begin{array}{l}.042^{*} \\
(.022)\end{array}$ \\
\hline 7 years & $\begin{array}{c}-.018 \\
(.015)\end{array}$ & $\begin{array}{l}.022 \\
(.029)\end{array}$ & $\begin{array}{c}-.014 \\
(.021)\end{array}$ & $\begin{array}{c}-.057 \% * \\
(.017)\end{array}$ & $\begin{array}{l}.046^{* *} \\
(.023)\end{array}$ \\
\hline 8 years & $\begin{array}{c}-.004 \\
(.016)\end{array}$ & $\begin{array}{c}.032 \\
(.029)\end{array}$ & $\begin{array}{c}.001 \\
(.019)\end{array}$ & $\begin{array}{c}-.034 * * \\
(.017)\end{array}$ & $\begin{array}{l}.050 \% * \\
(.024)\end{array}$ \\
\hline 9 years & $\begin{array}{c}-.042 \% \\
(.016)\end{array}$ & $\begin{array}{l}.072 \% * \\
(.031)\end{array}$ & $\begin{array}{c}-.021 \\
(.021)\end{array}$ & $\begin{array}{c}.002 \\
(.017)\end{array}$ & $\begin{array}{l}.048^{*} \\
(.026)\end{array}$ \\
\hline 10 years & $\begin{array}{l}.012 \\
. .017)\end{array}$ & $\begin{array}{l}.004 \\
(.032)\end{array}$ & $\begin{array}{c}-.002 \\
(.021)\end{array}$ & $\begin{array}{c}-.004 \\
(.018)\end{array}$ & $\begin{array}{c}.043 \\
.027)\end{array}$ \\
\hline Constant & $\begin{array}{l}8.195^{* * *} \\
(.007)\end{array}$ & $\begin{array}{l}4.611^{* * *} \\
(.014)\end{array}$ & $\begin{array}{l}2.793 \% * \\
(.037)\end{array}$ & $\begin{array}{l}8.438^{* * *} \\
(.009)\end{array}$ & $\begin{array}{l}7.136 \% * \\
(.010)\end{array}$ \\
\hline \multicolumn{6}{|l|}{$F$-test of no } \\
\hline union effect & $\begin{array}{c}10.21 \\
{[.00]}\end{array}$ & $\begin{array}{l}6.92 \\
{[.00]}\end{array}$ & $\begin{array}{c}.89 \\
{[.55]}\end{array}$ & $\begin{array}{l}8.70 \\
{[.00]}\end{array}$ & $\begin{array}{l}1.78 \\
{[.05]}\end{array}$ \\
\hline$N$ & 7,518 & 7,518 & 7,078 & 10,250 & 10,703 \\
\hline No. of clusters & 1,027 & 1,027 & 1,027 & 1,027 & 1,027 \\
\hline$R^{2}$ & .711 & .975 & .615 & .566 & .983 \\
\hline \multicolumn{6}{|c|}{$\begin{array}{l}\text { NoTE.-The analysis sample includes only district-year observations with time to unionization less } \\
\text { than or equal to } 10 \text { years. Regressions include school district and year fixed effects. The variable years } \\
\text { relative to unionization is the number of years relative to election certification, which includes negative } \\
\text { values for years prior to certification. All standard errors are clustered at the school district level and } \\
\text { are shown in parentheses. The } F \text {-test of no union effect is a test for joint significance of the union age } \\
\text { dummy coefficients. The } p \text {-values of the test for joint significance are presented in brackets beneath the } \\
F \text {-statistic. } \\
* \text { Significant at the } 10 \% \text { level. } \\
* \text { Significant at the } 5 \% \text { level. }\end{array}$} \\
\hline
\end{tabular}


cannot employ the difference-in-difference methodology given by equation (2) due to the fact there are relative years to union election with few observations. Instead, I impose a linear structure on the time pattern of teacher union effects, though results are unchanged if I allow for quadratic time patterns. I estimate linear education production functions of the form:

$$
\begin{aligned}
\text { Dropout Rate }= & \beta_{0}+\beta_{1} \text { Union }_{i s t} \\
& \left.+\beta_{2} \text { Union } \times \text { (Years relative to unionization }\right)_{i s t} \\
& +\beta_{3}(\text { Years relative to unionization })_{i s t} \\
& +\delta X_{i s t}+\tau_{i}+\phi_{s t}+\varepsilon_{i s t}
\end{aligned}
$$

where all union variables are defined the same as in table 3 (see Sec. III.C.2), ${ }^{31} X$ is a vector of demographic characteristics that are listed in Section II.B, and all other variables are as previously defined. ${ }^{32}$ The coefficient on Union $\times$ (Years relative to unionization) ist identifies the existence and magnitude of time-varying union effects on high school dropout rates, while the coefficient on Years relative to unionization will detect selection into unionization based on high school dropout rate trends.

Results from estimation of equation (4) are presented in table 5. When the union age terms are excluded, there is no apparent effect of teachers' unions on high school dropout rates: the coefficient on the union dummy is 0.100 and is not statistically significant at even the $10 \%$ level. However, when union age is added to the model, column 2 shows that unionization is associated with a 1.8 percentage point increase in high school dropout rates in the short run but in the long run is associated with a decrease in dropout rates. The estimates imply that after 7.7 years the union effect on dropout rates becomes negative. As column 3 shows, this result is basically unchanged by controlling for union age prior to unionization, which suggests that selection effects are negligible in this context.

The results presented in table 5 are suggestive that unions do not affect high school dropout rates, at least on average. As discussed in Section I, unions likely change many of the aspects of the teacher-administrator relationship, each of which has a different implication for teacher pro-

${ }^{31}$ In eq. (4) and table 4, the variable years relative to unionization includes nonzero values for all negative union ages, whereas in table 3 , years relative to unionization is set to zero for all values less than -5 .

${ }^{32}$ The education production function given by (4) is admittedly crude in the sense that I am unable to control for student-level factors such as previous test scores and a vector of historical educational inputs. This limitation is necessitated by the data, but under the assumption that unionization is conditionally exogenous, which has been the identifying assumption throughout the analysis, the exercise still yields insight into the relationship between teachers' unions and high school dropout rates. 
Table 5

Effect of Teachers' Unions on High School Dropout Rates, 1970-90

\begin{tabular}{|c|c|c|c|}
\hline \multirow[b]{2}{*}{ Independent Variable } & \multicolumn{3}{|c|}{$\begin{array}{l}\text { Dependent Variable: High School } \\
\text { Dropout Rate in Percent }\end{array}$} \\
\hline & (1) & (2) & (3) \\
\hline Union & .100 & $1.809 *$ & $\begin{array}{l}2.103 \% * \\
(1.058)\end{array}$ \\
\hline Union $\times$ (Years relative to unionization $)$ & & $\begin{array}{l}-.235 \% * \\
(.093)\end{array}$ & $\begin{array}{l}-.190 * * \\
(.124)\end{array}$ \\
\hline Years relative to unionization & & & $\begin{array}{l}-.095 \\
(.124)\end{array}$ \\
\hline Log population & $\begin{array}{l}23.482^{* * *} \\
(3.624)\end{array}$ & $\begin{array}{c}23.538^{* * *} \\
(3.620)\end{array}$ & $\begin{array}{c}23.557 * * \\
(3.610)\end{array}$ \\
\hline$\%$ Urban & $\begin{array}{l}1.633^{* *} \\
(.700)\end{array}$ & $\begin{array}{l}1.545 * * \\
(.700)\end{array}$ & $\begin{array}{l}1.517 \% \\
(.703)\end{array}$ \\
\hline Log Average income & $\begin{array}{c}-13.861^{*} \\
(3.216)\end{array}$ & $\begin{array}{c}-13.376 * \\
(3.192)\end{array}$ & $\begin{array}{c}-13.326 \% \\
(3.190)\end{array}$ \\
\hline Log Median rent & $\begin{array}{c}2.338 \\
(1.788)\end{array}$ & $\begin{array}{l}2.207 \\
(1.779)\end{array}$ & $\begin{array}{c}2.125 \\
(1.768)\end{array}$ \\
\hline$\%$ Below poverty & $\begin{array}{l}-.208^{* *} \\
(.100)\end{array}$ & $\begin{array}{l}-.194 \% * \\
(.099)\end{array}$ & $\begin{array}{l}-.194 * \% \\
(.099)\end{array}$ \\
\hline$\%$ Unemployed & $\begin{array}{c}-.050 \\
(.099)\end{array}$ & $\begin{array}{c}-.026 \\
(.099)\end{array}$ & $\begin{array}{c}-.025 \\
(.099)\end{array}$ \\
\hline$\%$ Black & $\begin{array}{l}.057 \\
(.371)\end{array}$ & .138 & $\begin{array}{l}.139 \\
(.377)\end{array}$ \\
\hline$\%$ Hispanic & $\begin{array}{l}.266 \\
(.251)\end{array}$ & $\begin{array}{l}.317 \\
(.252)\end{array}$ & $\begin{array}{l}.328 \\
(.250)\end{array}$ \\
\hline$\%$ 12-15 years school & $\begin{array}{l}.009 \\
(.069)\end{array}$ & $\begin{array}{l}.022 \\
(.070)\end{array}$ & $\begin{array}{l}.023 \\
(.070)\end{array}$ \\
\hline$\% 16+$ years school & $\begin{array}{l}.263 * * \\
(.076)\end{array}$ & $\begin{array}{l}.256 \% * \\
(.076)\end{array}$ & $\begin{array}{l}.258^{* * *} \\
.076)\end{array}$ \\
\hline$\%$ Private enrollment & $\begin{array}{c}-.201 \% * \\
(.088)\end{array}$ & $\begin{array}{c}-.208 \% \\
(.087)\end{array}$ & $\begin{array}{c}-.207^{* * *} \\
(.088)\end{array}$ \\
\hline Log Public school enrollment & $\begin{array}{l}-22.446 * \% \\
(3.209)\end{array}$ & $\begin{array}{l}-22.483 * * \\
(3.194)\end{array}$ & $\begin{array}{l}-22.505^{* \%} \\
(3.180)\end{array}$ \\
\hline Constant & $\begin{array}{c}-18.693 \\
(14.967)\end{array}$ & $\begin{array}{c}-19.441 \\
(15.131)\end{array}$ & $\begin{array}{l}-19.237 \\
(15.154)\end{array}$ \\
\hline
\end{tabular}

Source.-Author's calculation as described in the text from the 1970, 1980, and 1990 U.S. Census School District Files.

NoтE.-The variable years relative to unionization is the number of years relative to election certification, which includes negative values for years prior to certification. For districts that do not unionize, years relative to unionization is set to zero. The variable union is a dummy variable equal to one if a district has successfully unionized as of that calendar year. All models include state-by-year and school district fixed effects. Standard errors are clustered at the school district level and are in parentheses.

* Significant at the $10 \%$ level.

$*$ Significant at the 5\% level.

ductivity. For example, by making it more difficult to fire teachers and by linking pay to experience and education level instead of to output, unions can reduce teacher productivity. However, unions can be productivity enhancing by protecting teachers from bad administrative practices and giving them a voice with which to influence their workplace. Table 5 is suggestive either that unions have no effect on productivity or that the positive productivity effects of unionization are canceled out by the negative effects. How teachers' unions influence the effectiveness of educational inputs is an important topic for future research. 


\section{Discussion}

Taken together, the results presented above indicate that teachers' unions have little net effect on resource allocation and student educational attainment. What theories of school district and union behavior might be consistent with my findings? One model that fits into the context of the above results is Tiebout sorting (Tiebout 1956). Tiebout sorting could occur due to the increases in teacher employment and current operating expenditures per student directly after unionization. To the extent that parents value these increased resource levels, enrollment in unionized districts should increase relative to nonunionized districts, which is what the data show. These results are thus consistent with the larger literature on parental valuation of school resources (Black 1999; Brasington 1999). Such studies typically present evidence that more school resources lead to increased demand among parents as measured by changes in housing prices. It is natural to expect increases in demand to lead to enrollment increases as well.

That the relative enrollment increases found in my analysis are of the same magnitude as the teacher employment effects and that they occur gradually after the unionization decision is highly suggestive that they are in response to the shift in resources post-unionization. Conversely, unions may be reacting to expected relative enrollment increases in their district to force the administration to keep class sizes and expenditures per student roughly constant. Both models of union behavior will produce the data patterns reported in Section III. To test the latter explanation, I use the age distribution in each school district from the 1980 U.S. Census to explore whether the $0-5$ age population in any given year has power in predicting the timing of the unionization election. I find no evidence of correlation between union vote timing and forecastable population in the school district. Furthermore, because the cities are more likely to unionize, any macroeconomic shock that caused an increase in urban versus rural population in the 1970s could explain the enrollment result. Appendix figure B4 shows trends in log enrollment among urban and rural districts for the three states in this study and for the 18 states without duty-to-bargain laws. ${ }^{33}$ The figure shows no evidence of enrollment shifts in the nonunion states, but the rural districts in Iowa, Indiana, and Minnesota, which contain virtually all of the nonunionized districts, experienced declining enrollment beginning in the mid-1970s relative to urban districts. For a macroeconomic shock to explain this shift, it must be occurring in these three states and not in the nonunion states.

I also estimate equation (2) using only rural districts. The results of this exercise are reported in table B3 and are both qualitatively and quan-

\footnotetext{
${ }^{33}$ Rural districts are those that have no census block points in an urban area at
} any point in the sample period. The remainder of districts are classified as urban. 
titatively similar to those presented above. The results therefore point to a Tiebout sorting explanation for the relative enrollment increases in unionized districts rather than evidence of selection into unionization based on beliefs about future enrollment changes or growth in city versus rural populations. That the relative enrollment increases in unionized districts negates any class size and per student expenditure gains from rising employment and expenditure levels following unionization, however, is unambiguous in the data.

Another explanation for my results is that teachers' unions simply may be ineffective at influencing resource allocation. This could occur if unions face restrictive district budget constraints; if there are few rents to extract, the unions will not be able to affect school district budgets regardless of their underlying goals. Further, union aggressiveness in extracting rents may be limited by a fear of taxpayer backlash at the local level. It remains an open question in the literature whether teacher unionization causes tax revolts, but unions may react to this possibility by reducing the degree to which they attempt to influence educational inputs. Teachers' unions also may achieve nonsalary benefits for teachers, such as health care and pensions, ${ }^{34}$ as well as give teachers a voice in setting work rules and practices (Retsinas 1982; Murphy 1990; Moe 2001; Johnson 2004). While the data on such outcomes are difficult to obtain, examining union impacts on these factors is an important area for future work.

My union impact estimates differ both quantitatively and qualitatively from much of the established literature on teachers' union effects. One plausible explanation for these differences is that unions have different effects in Iowa, Indiana, and Minnesota than in the rest of the United States. Another explanation, however, is that the union election data more accurately capture the timing and extent of teacher unionization than previous measures have. In order to gain insight into the differences between my estimates and previous estimates in the literature, appendix table $\mathrm{C} 1$ compares my union measure with the union measure constructed from the Census of Governments Labor Relations Surveys, used most notably in Hoxby (1996). There are substantial differences across the two measures that strongly suggest that measurement error exists in the COG union measure. Interpreting all differences between the union certification measure and the COG union measure as measurement error in the latter, I find misclassification rates of up to $47 \%$ in the Census of Governments.

Appendix $\mathrm{C}$ also presents replications of the analysis from Hoxby (1996) using my sample of three states and both union measures in order to determine the relevance of the differences in union measures on union

\footnotetext{
${ }^{34}$ Freeman (1986) cites evidence that public sector unions raise non-wage benefits by more than they raise wages, though the evidence is scant for teachers' unions. Freeman (1981) finds the same effect for private sector unions.
} 
impact estimates. Although the results of this replication are somewhat inconclusive due to large standard errors, my estimates using the COG union measure, particularly for teacher pay, are consistent with those presented in Hoxby (1996), but I find that using my union measure produces substantively different estimates. I then undertake an analysis of the properties of the measurement error in the COG union measure, treating the election certification data as the true measure of union status for each school district. I find that the measurement error in the Census of Governments is correlated with the outcome variables used in this analysis, which implies that the bias is not guaranteed to attenuate the coefficient estimates because it is correlated with teacher salary, per student expenditure, class size, and high school dropout rate changes at the school district level (Bound, Brown, and Mathiowetz 2001). I also perform Bound et al. (1994) decompositions that decompose the measurement error into the part that is due to misclassification of union status and the part that is due to the correlation of this misclassification with the regression error. My results indicate that both forms of bias are present and reinforce each other for teacher pay, COE per student, and student-teacher ratios but work in opposite directions for high school dropout rates. The central implication of the results presented in appendix $\mathrm{C}$ is that obtaining accurate measures of union status and unionization timing is critical to obtaining accurate estimates of union impacts.

\section{Conclusion}

Using new hand-collected data on the timing of teachers' union election certifications in Iowa, Indiana, and Minnesota combined with school district-level data from the Census/Survey of Governments, I investigate the impact of teachers' unions on school district educational resources. Contrary to many past studies on teachers' unions (Baugh and Stone 1982; Freeman 1986; Moore and Raisian 1987; Hoxby 1996), I find that unions have no effect on teacher pay. I also present evidence that teacher unionization causes an increase in full-time teacher employment of about $5 \%$, a negligible decrease in student-teacher ratios, and only has a short-run positive effect on current operating expenditures per student.

I estimate the impact of unions on high school dropout rates using 1970-1990 U.S. Census school district summary data and find little evidence that unions affect this outcome measure. However, I am unable to determine with my data whether similar results would be found for other achievement measures that include more students from higher portions of the ability distribution.

The results and conclusions of this analysis raise a puzzle: why do teachers bother to organize, especially at the high rates observed in the data, given the lack of wage and class size effects? One possible answer 
to this puzzle is that teachers perceive that organization increases their pay. Indeed, when talking to union members during this study, wage increases were the most commonly mentioned benefit of unionization, in contrast to what this analysis shows. Another important reason for unionizing is to give teachers a voice with which to improve their working conditions as well as to establish well-defined rules governing hiring and firing, pay structure, and promotion. There is anecdotal evidence teachers' unions provide these benefits (Woodbury 1985), although I lack the data to test for such effects. Finally, unionization may increase nonwage benefits such as pensions or health care that are valued by teachers. Unionization thus can influence how satisfied teachers are with their job, and consequently, may affect parent and student satisfaction with their school district.

One must be careful in drawing too general a conclusion from the results presented above, as this study includes only three states concentrated in the Midwest. Rather than interpreting my results as representative of union impacts for the United States as a whole, one can view this study as provocative in suggesting the commonly accepted effects of teachers' unions-raising wages and reducing teacher productivity-may not be robust to the use of more accurate union data. The main implication of this study is more research using such data is necessary to understand more fully the nature and impact of collective bargaining in public education and to inform meaningful labor relations policy.

\section{Appendix A}

\section{Census and Survey of Governments}

The Census of Governments (COG) has been conducted every 5 years beginning in 1957; however, data only are available electronically starting in 1972. The survey contains expenditure and employment data for every independent government in the United States, including independent school districts. Independent school districts are those deemed separate enough from other local governments that they are considered their own autonomous government. In Iowa and Indiana, all school districts are independent. In Minnesota, however, about $7 \%$ of students are enrolled in dependent school districts. Thus, the universe of school districts in the COG/SOG is close to the full universe of school districts in the three states included in this analysis.

The Survey of Governments (SOG) has been conducted in each nonCOG year beginning in 1973. It contains a random sample of local governments included in the previous census. In 1979, the Census Bureau began sampling every school district in certain states (including Iowa and Minnesota) for their Annual Survey of Local Government Finances: School 
Systems (F-33). The employment survey, which is conducted separately, remained a random sample for all states.

Because the Census Bureau does not code school districts in a systematic manner, the only way to combine information across years is to merge files based on district name. However, in the 1975 finance file and the 1986 finance and employment files, these names are missing. Thus, I am forced to exclude data from these survey years from the analysis. I do use the 1975 employment data, however.

I construct measures of real monthly full-time teacher pay, full-time teacher employment, student-teacher ratios, and current operating expenditures (COE) for each district in the sample. All financial variables are inflated to real 2004 dollars using the CPI-U. The definitions of most of these variables are straightforward and come directly from the COG/ SOG, with the exception of teacher pay and the student-teacher ratio.

I construct real monthly full-time teacher pay by dividing the gross monthly payroll for full-time instructional staff by the number of fulltime instructional staff. Full-time staff are defined by the number of hours they are paid to work; both full-time and part-time teacher employment include the same categories of staff members. Note also that, in the COG/ SOG data, "teachers" include educational support staff and school-level administrators, such as principals and guidance counselors. However, other administrators, such as the superintendent, are excluded from this category. Unfortunately, there are no district-level data from this period on teacher pay that will allow me to narrow this group further. To the extent that unions affect the mix of full-time teachers in the school district through changes in seniority rules and hiring practices, the impact on teacher pay only will be detected if these changes shift the mean salary of teachers.

The student-teacher ratio is my measure of class size (Woodbury [1985] and Hoxby [1996] also use this measure). I calculate the student-teacher ratio by dividing total enrollment by the number of full-time equivalent teachers in each school district. While this ratio does not measure the exact number of students included in each class, it is a reasonable and standard approximation of the human resources per student in each district. 


\section{Appendix B}

\section{Supplemental Figures and Tables}
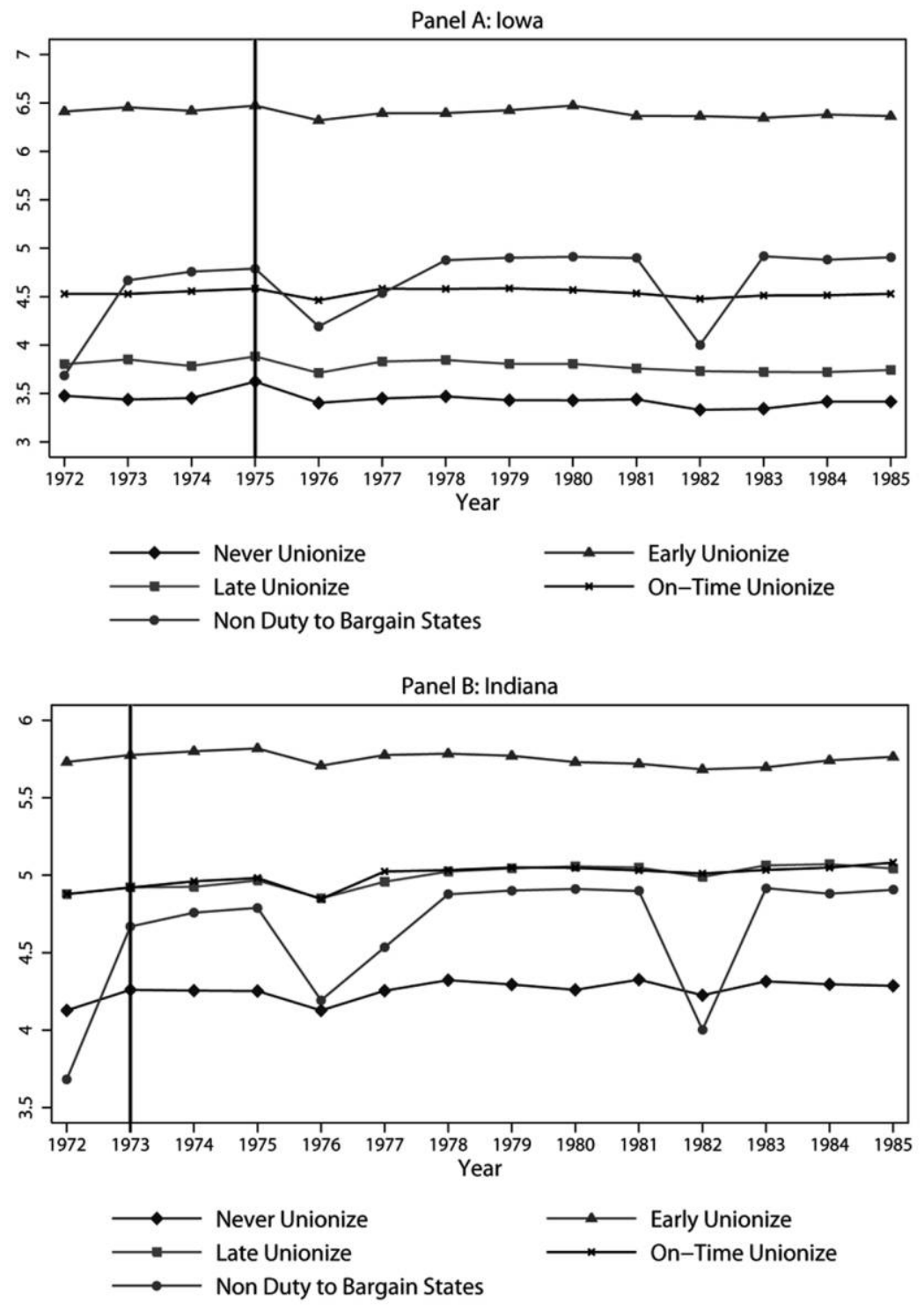
Panel C: Minnesota

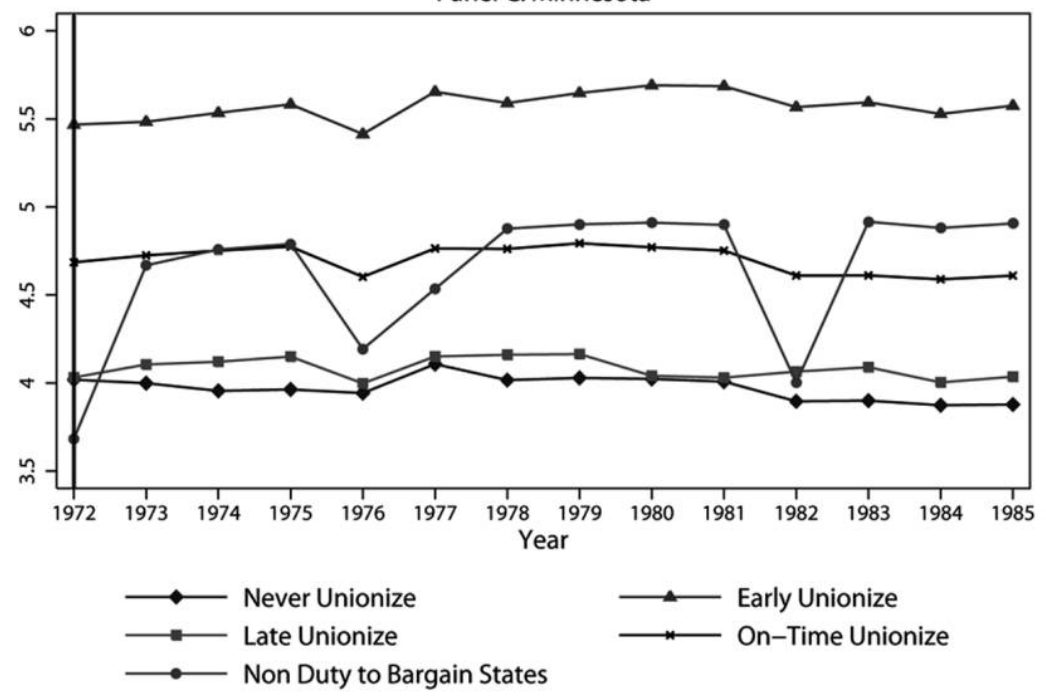

FIG. B1.-Trends in log full-time teacher employment by state. The data come from the teachers' union election certification data and Census/Survey of Governments as described in the text. In each panel, the vertical line represents the year in which a duty-to-bargain law was passed in the state. "Never Unionize" districts are those that do not have a successful union election vote by 2004, "Early Unionize" districts are those that unionize prior to passage of their state's duty-to-bargain law, "Late Unionize" districts are those that unionize more than one year after passage of their state's duty-to-bargain law, and "On-Time Unionize" districts are those that unionize within 1 year of passage of their state's duty-tobargain law. "Non Duty to Bargain States" are the 18 states that did not have a duty-tobargain law as of 1982: Alabama, Arkansas, Arizona, Colorado, Georgia, Illinois, Kentucky, Louisiana, Missouri, Mississippi, Nebraska, New Mexico, Ohio, South Carolina, Texas, Utah, West Virginia, and Wyoming. 

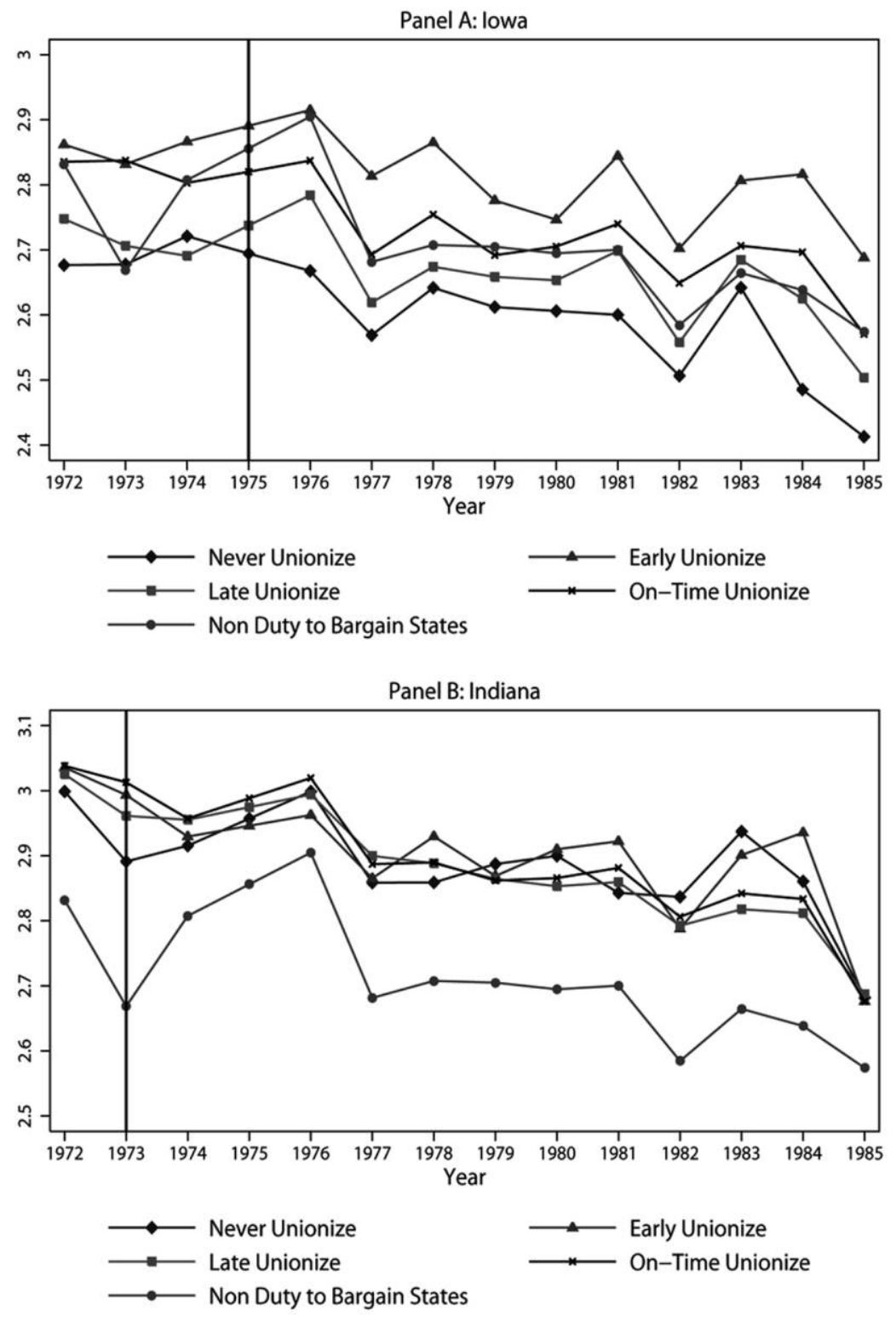


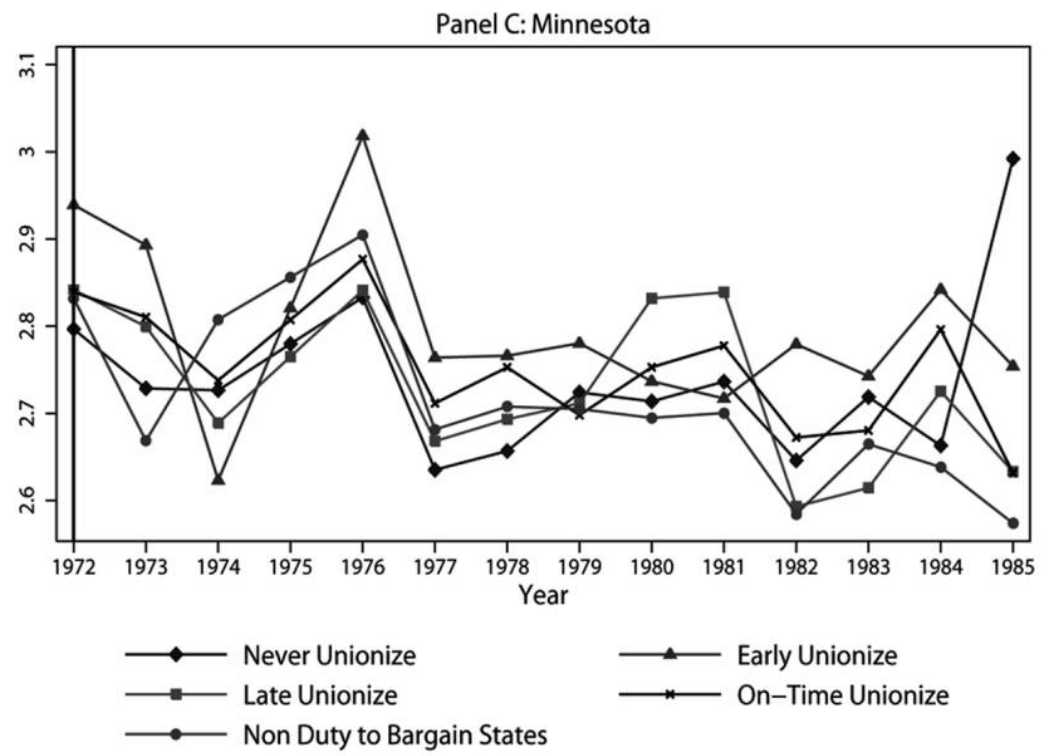

FIG. B2.-Trends in log student-teacher ratios by state. The data come from the teachers' union election certification data and Census/Survey of Governments, as described in the text. In each panel, the vertical line represents the year in which a duty-to-bargain law was passed in the state. "Never Unionize" districts are those that do not have a successful union election vote by 2004, "Early Unionize" districts are those that unionize prior to passage of their state's duty-to-bargain law, "Late Unionize" districts are those that unionize more than one year after passage of their state's duty-to-bargain law, and "On-Time Unionize" districts are those that unionize within 1 year of passage of their state's duty-to-bargain law. "Non Duty to Bargain States" are the 18 states that did not have a duty-to-bargain law as of 1982: Alabama, Arkansas, Arizona, Colorado, Georgia, Illinois, Kentucky, Louisiana, Missouri, Mississippi, Nebraska, New Mexico, Ohio, South Carolina, Texas, Utah, West Virginia, and Wyoming. 

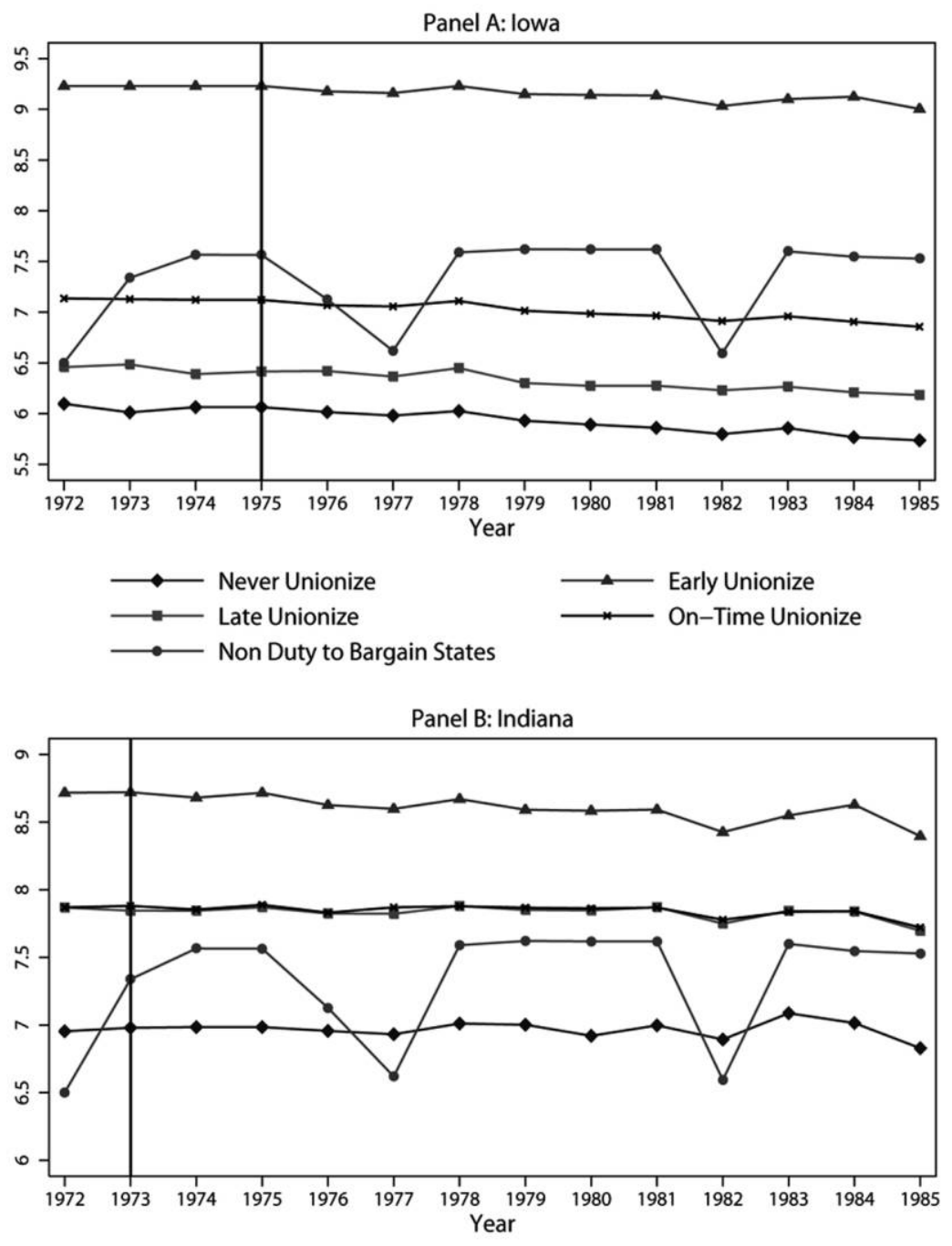

$\longrightarrow-$ Never Unionize
$\longrightarrow-$ Late Unionize
$\longrightarrow-$ Non Duty to Bargain States 

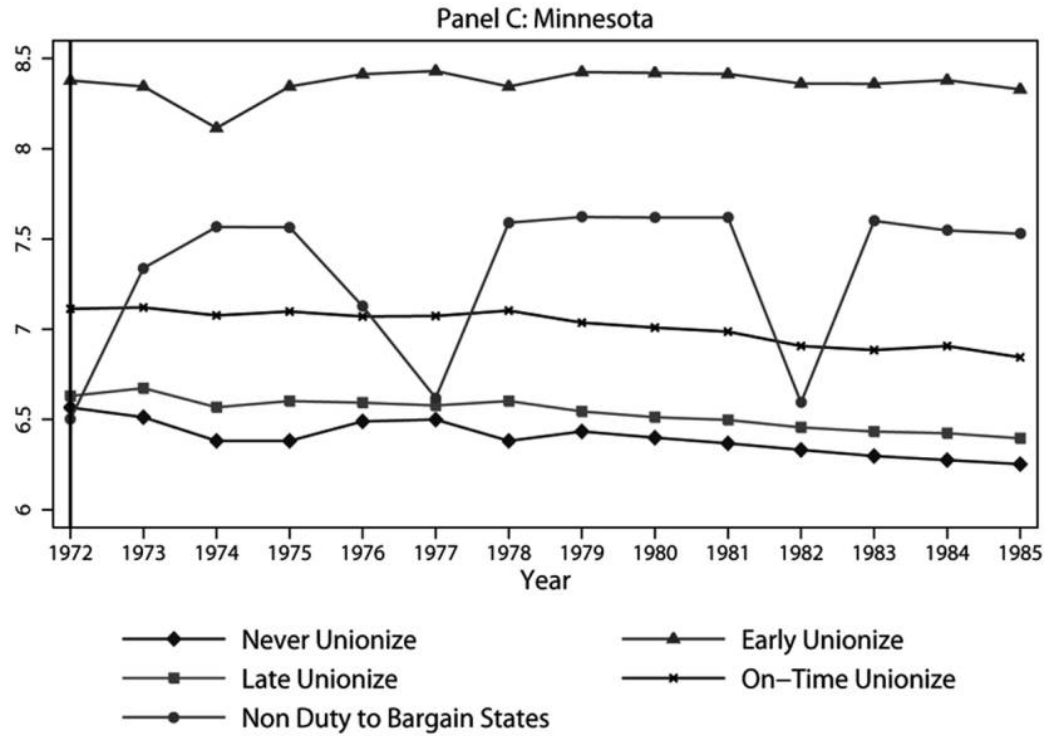

FIG. B3.-Trends in log enrollment by state. The data come from the teachers' union election certification data and Census/Survey of Governments, as described in the text. In each panel, the vertical line represents the year in which a duty-to-bargain law was passed in the state. "Never Unionize" districts are those that do not have a successful union election vote by 2004, "Early Unionize" districts are those that unionize prior to passage of their state's duty-to-bargain law, "Late Unionize" districts are those that unionize more than 1 year after passage of their state's duty-to-bargain law, and "On-Time Unionize" districts are those that unionize within 1 year of passage of their state's duty-to-bargain law. "Non Duty to Bargain States" are the 18 states that did not have a duty-to-bargain law as of 1982: Alabama, Arkansas, Arizona, Colorado, Georgia, Illinois, Kentucky, Louisiana, Missouri, Mississippi, Nebraska, New Mexico, Ohio, South Carolina, Texas, Utah, West Virginia, and Wyoming. 


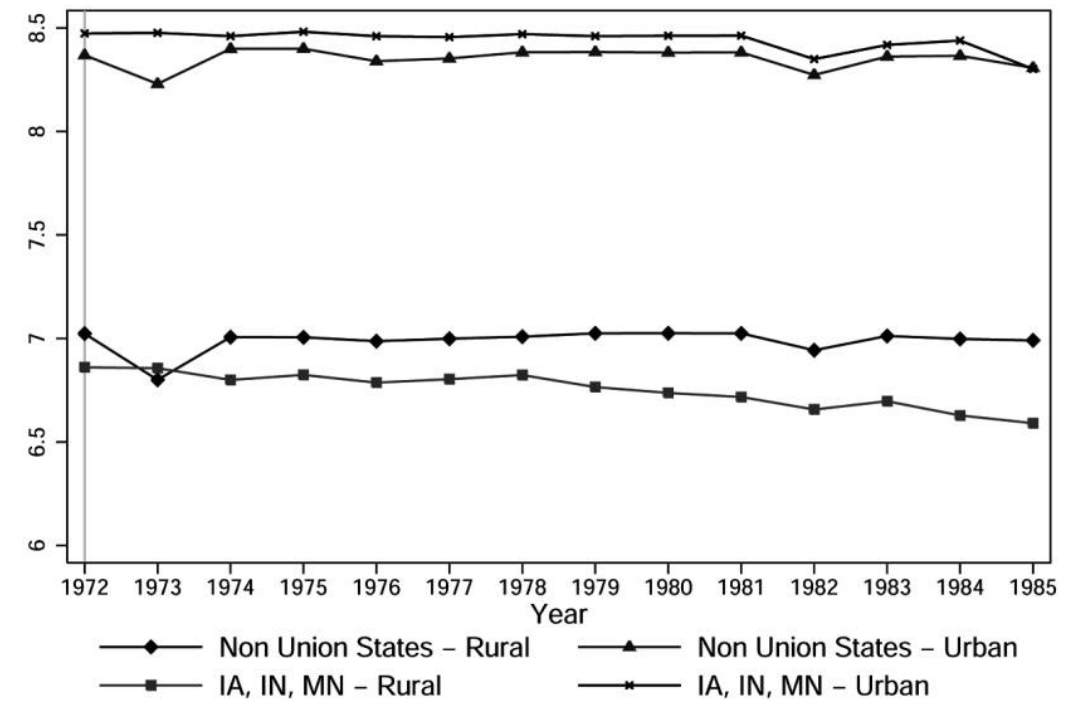

FIG. B4.-Trends in log enrollment among union and nonunion states. The data come from the teachers' union election certification data and Census/Survey of Governments, as described in the text. Rural districts are those that do not have a Census block point in an urban area at any time during the sample period. Urban districts comprise the remainder of school districts. "Non Union States" are the 18 states that did not have a duty-to-bargain law as of 1982: Alabama, Arkansas, Arizona, Colorado, Georgia, Illinois, Kentucky, Louisiana, Missouri, Mississippi, Nebraska, New Mexico, Ohio, South Carolina, Texas, Utah, West Virginia, and Wyoming. 


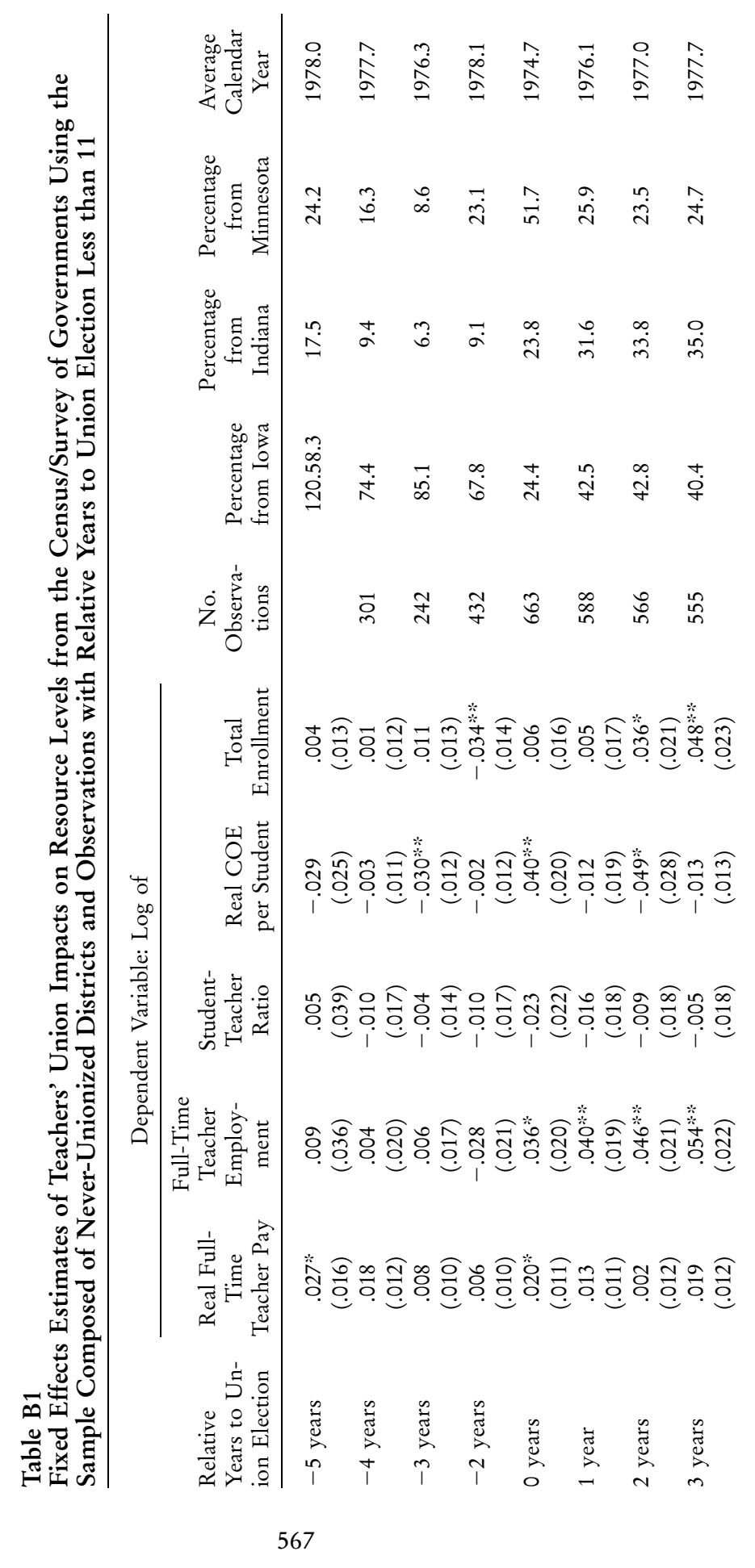




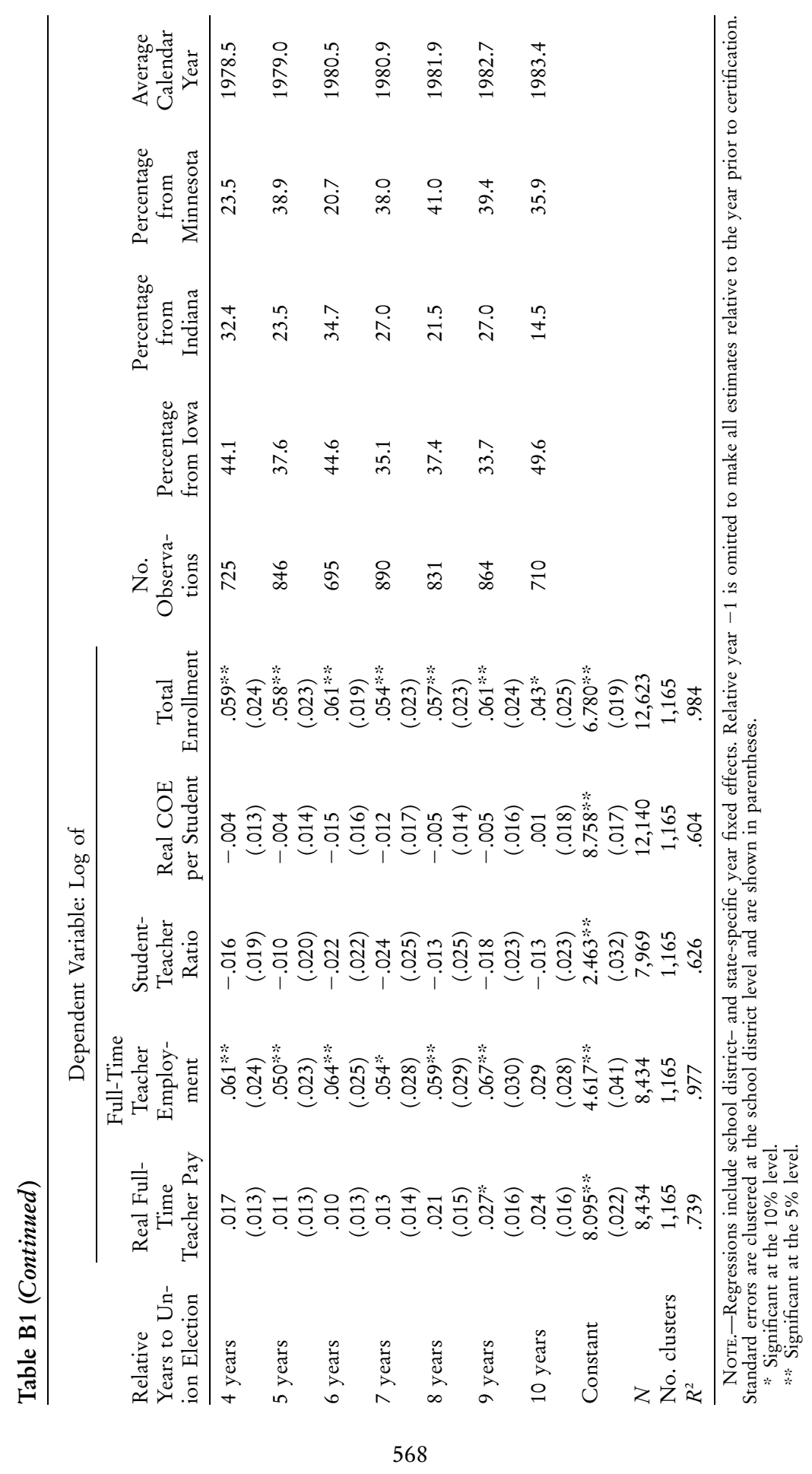


Table B2

Fixed Effects Estimates of Teachers' Union Impacts on Resource Levels from the Census/Survey of Governments Using a Balanced Panel of Districts That Are Observed in Every Year of the Sample

\begin{tabular}{|c|c|c|c|c|c|}
\hline \multirow{2}{*}{$\begin{array}{l}\text { Relative } \\
\text { Years to } \\
\text { Union } \\
\text { Election }\end{array}$} & \multicolumn{5}{|c|}{ Dependent Variable: Log of } \\
\hline & $\begin{array}{c}\text { Real } \\
\text { Full-Time } \\
\text { Teacher Pay }\end{array}$ & $\begin{array}{c}\text { Full-Time } \\
\text { Teacher } \\
\text { Employment }\end{array}$ & $\begin{array}{c}\text { Student-Teacher } \\
\text { Ratio }\end{array}$ & $\begin{array}{l}\text { Real } \\
\text { COE per } \\
\text { Student }\end{array}$ & $\begin{array}{c}\text { Total } \\
\text { Enrollment }\end{array}$ \\
\hline \multirow[t]{2}{*}{-5 years } & .017 & .029 & -.024 & -.153 & .015 \\
\hline & $(.021)$ & $(.026)$ & $(.022)$ & $(.135)$ & $(.027)$ \\
\hline \multirow[t]{2}{*}{-4 years } & .038 & -.016 & .002 & -.006 & -.018 \\
\hline & $(.032)$ & $(.027)$ & $(.016)$ & $(.032)$ & $(.026)$ \\
\hline \multirow[t]{2}{*}{-3 years } & .009 & .012 & -.010 & -.014 & .004 \\
\hline & $(.019)$ & $(.023)$ & $(.021)$ & $(.029)$ & $(.020)$ \\
\hline \multirow{2}{*}{-2 years } & .010 & -.022 & -.019 & .032 & -.042 \\
\hline & $(.017)$ & $(.023)$ & $(.028)$ & $(.028)$ & $(.028)$ \\
\hline \multirow{2}{*}{0 years } & .025 & .029 & -.018 & $.076 \%$ & .004 \\
\hline & $(.022)$ & $(.022)$ & $(.024)$ & $(.039)$ & $(.016)$ \\
\hline \multirow[t]{2}{*}{1 year } & .023 & .016 & -.005 & .023 & .005 \\
\hline & $(.023)$ & $(.027)$ & $(.027)$ & $(.039)$ & $(.021)$ \\
\hline \multirow[t]{2}{*}{2 years } & .023 & .021 & .002 & -.081 & .036 \\
\hline & $(.024)$ & $(.033)$ & $(.033)$ & $(.078)$ & $(.032)$ \\
\hline \multirow[t]{2}{*}{3 years } & .027 & .047 & -.012 & -.010 & .043 \\
\hline & $(.025)$ & $(.036)$ & $(.026)$ & $(.031)$ & $(.039)$ \\
\hline \multirow[t]{2}{*}{4 years } & .032 & .045 & -.023 & .026 & .034 \\
\hline & $(.027)$ & $(.040)$ & $(.029)$ & $(.026)$ & $(.043)$ \\
\hline \multirow[t]{2}{*}{5 years } & .021 & .050 & -.015 & .027 & .048 \\
\hline & $(.030)$ & $(.044)$ & $(.030)$ & $(.027)$ & $(.050)$ \\
\hline \multirow[t]{2}{*}{6 years } & .012 & .067 & -.039 & .034 & .049 \\
\hline & $(.029)$ & $(.049)$ & $(.034)$ & $(.029)$ & $(.052)$ \\
\hline \multirow[t]{2}{*}{7 years } & .026 & .021 & -.013 & -.003 & .042 \\
\hline & $(.030)$ & $(.054)$ & $(.039)$ & $(.035)$ & $(.058)$ \\
\hline \multirow[t]{2}{*}{8 years } & .020 & .035 & -.007 & .012 & .046 \\
\hline & $(.033)$ & $(.056)$ & $(.032)$ & $(.030)$ & $(.061)$ \\
\hline \multirow[t]{2}{*}{9 years } & .019 & .032 & -.002 & .012 & .031 \\
\hline & $(.036)$ & $(.059)$ & $(.036)$ & $(.033)$ & $(.059)$ \\
\hline \multirow[t]{2}{*}{10 years } & .005 & .019 & -.044 & .043 & -.013 \\
\hline & $(.036)$ & $(.062)$ & $(.036)$ & $(.036)$ & $(.058)$ \\
\hline \multirow[t]{2}{*}{ Constant } & $8.225 \% *$ & $5.650 * *$ & $2.565 \%$ & $8.697 * *$ & $8.226 * *$ \\
\hline & $(.033)$ & $(.068)$ & $(.033)$ & $(.035)$ & $(.060)$ \\
\hline$N$ & 3,683 & 3,684 & 3,474 & 3,835 & 4,047 \\
\hline No. clusters & 213 & 213 & 213 & 213 & 213 \\
\hline$R^{2}$ & .737 & .964 & .526 & .590 & .976 \\
\hline \multicolumn{6}{|c|}{ 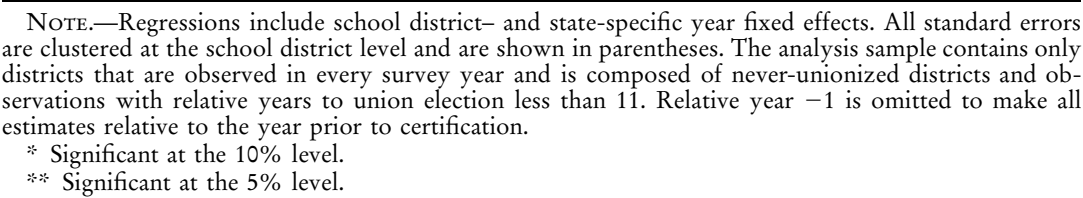 } \\
\hline
\end{tabular}


Table B3

Fixed Effects Estimates of Teachers' Union Impacts on Resource Levels from the Census/Survey of Governments-Rural Districts Only

\begin{tabular}{|c|c|c|c|c|c|}
\hline \multirow{4}{*}{$\begin{array}{l}\text { Relative } \\
\text { Years to } \\
\text { Union } \\
\text { Election }\end{array}$} & \multicolumn{5}{|c|}{ Dependent Variable: Log of } \\
\hline & Real & Full-Time & & Real & \\
\hline & Full-Time & Teacher & Student-Teacher & COE per & Total \\
\hline & Teacher Pay & Employment & Ratio & Student & Enrollment \\
\hline \multirow{2}{*}{-5 years } & .027 & -.004 & .009 & -.004 & .001 \\
\hline & $(.018)$ & $(.038)$ & $(.056)$ & $(.012)$ & $(.014)$ \\
\hline \multirow[t]{2}{*}{-4 years } & .017 & .020 & -.022 & -.006 & .004 \\
\hline & $(.012)$ & $(.021)$ & $(.016)$ & $(.013)$ & $(.013)$ \\
\hline \multirow{2}{*}{-3 years } & .006 & .009 & -.009 & $-.027 \%$ & .010 \\
\hline & $(.011)$ & $(.019)$ & $(.016)$ & $(.014)$ & $(.014)$ \\
\hline \multirow{2}{*}{-2 years } & .012 & -.021 & -.013 & .004 & $-.031 \%$ \\
\hline & $(.011)$ & $(.020)$ & $(.018)$ & $(.014)$ & $(.014)$ \\
\hline \multirow[t]{2}{*}{0 years } & .015 & $.049 \%$ & -.040 & $.039 \%$ & .004 \\
\hline & $(.012)$ & $(.026)$ & $(.028)$ & $(.022)$ & $(.018)$ \\
\hline \multirow[t]{2}{*}{1 year } & .011 & $.048 * *$ & -.032 & .009 & -.003 \\
\hline & $(.012)$ & $(.023)$ & $(.021)$ & $(.015)$ & $(.019)$ \\
\hline \multirow[t]{2}{*}{2 years } & -.004 & $.045 \%$ & -.017 & -.017 & .022 \\
\hline & $(.014)$ & $(.023)$ & $(.021)$ & $(.028)$ & $(.022)$ \\
\hline \multirow[t]{2}{*}{3 years } & .013 & $.062 * *$ & -.017 & -.011 & .035 \\
\hline & $(.014)$ & $(.024)$ & $(.021)$ & $(.014)$ & $(.023)$ \\
\hline \multirow[t]{2}{*}{4 years } & .015 & $.063 \%$ & -.026 & .003 & $.042 \%$ \\
\hline & $(.014)$ & $(.026)$ & $(.024)$ & $(.014)$ & $(.024)$ \\
\hline \multirow[t]{2}{*}{5 years } & .014 & $.052 \%$ & -.019 & .002 & $.042 \%$ \\
\hline & $(.014)$ & $(.026)$ & $(.023)$ & $(.015)$ & $(.024)$ \\
\hline \multirow[t]{2}{*}{6 years } & .007 & $.071 \% *$ & -.036 & -.015 & $.047 * *$ \\
\hline & $(.014)$ & $(.027)$ & $(.026)$ & $(.016)$ & $(.024)$ \\
\hline \multirow[t]{2}{*}{7 years } & .007 & $.058 \%$ & -.038 & -.004 & $.042 \%$ \\
\hline & $(.016)$ & $(.033)$ & $(.031)$ & $(.018)$ & $(.023)$ \\
\hline \multirow[t]{2}{*}{8 years } & .014 & $.068 \%$ & -.033 & .004 & $.043 \%$ \\
\hline & $(.016)$ & $(.034)$ & $(.030)$ & $(.016)$ & $(.024)$ \\
\hline \multirow[t]{2}{*}{9 years } & .022 & $.074 * *$ & -.034 & .002 & .045 \\
\hline & $(.018)$ & $(.033)$ & $(.028)$ & $(.016)$ & $(.024)$ \\
\hline \multirow[t]{2}{*}{10 years } & .023 & .044 & -.032 & .010 & .031 \\
\hline & $(.017)$ & $(.030)$ & $(.026)$ & $(.018)$ & $(.026)$ \\
\hline \multirow[t]{2}{*}{ Constant } & $8.077 * *$ & $4.266 \%$ & $2.540 * *$ & $8.198 * *$ & $6.803 *$ \\
\hline & $(.023)$ & $(.033)$ & $(.037)$ & $(.015)$ & $(.016)$ \\
\hline$N$ & 6,659 & 6,659 & 6,333 & 10,408 & 10,754 \\
\hline No. clusters & 1,005 & 1,005 & 1,005 & 1,005 & 1,005 \\
\hline$R^{2}$ & .695 & .965 & .622 & .933 & .979 \\
\hline $\begin{array}{l}\text { Note.-Re } \\
\text { are clustered a } \\
\text { districts witho } \\
\text { and observatic } \\
\text { all estimates } \mathrm{r} \\
* \text { Significan } \\
* \text { Significa }\end{array}$ & $\begin{array}{l}\text { ions include } \\
\text { school distric } \\
\text { census block i } \\
\text { ith relative y } \\
\text { e to the year } \\
\text { the } 10 \% \text { level }\end{array}$ & $\begin{array}{l}\text { ol district- anc } \\
\text { vel and are sho } \\
\text { urban area in } \\
\text { to union elect } \\
\text { or to certificati }\end{array}$ & $\begin{array}{l}\text { ate-specific year } \\
\text { in parentheses. Th } \\
\text { year and is compc } \\
\text { less than } 11 \text {. Rela }\end{array}$ & $\begin{array}{l}\text { effects. Al } \\
\text { nalysis sam } \\
\text { of never-u } \\
\text { year }-1 \text { is }\end{array}$ & $\begin{array}{l}\text { andard errors } \\
\text { contains only } \\
\text { nized districts } \\
\text { hitted to make }\end{array}$ \\
\hline
\end{tabular}




\section{Appendix C}

\section{Classification Error in the Constructed Census of Governments Teachers' Union Measure}

\section{A Comparison of Alternative Unionization Measures}

As discussed in Section IV in the main text, my union impact estimates differ substantially from those in the established literature. In order to understand these differences more fully, it is instructive first to compare my union election certification data and the union measure constructed from the Census of Governments Labor Relations Survey (COG) used in Hoxby (1996), as this is the only other available district-level panel data union measure. The COG does not directly ask respondents about the existence of a teachers' union or a contract with that union. Instead, it contains three survey items related to labor relations that can be used to infer union status in a district:

1. Total number of full-time teachers who are members of an employee organization.

2. Does your agency engage in collective negotiations or meet and confer discussions with employee organizations for the purpose of reaching agreement on conditions of employment?

3. Total number of contractual agreements between your agency and employee organizations in effect as of October 15 of the survey year.

From these survey responses, one can construct a unionization measure using the following criteria: at least $50 \%$ of teachers are union members, the form of labor negotiations is collective bargaining, and the district has at least one contract or memorandum of understanding with any employee organization in effect as of October of the survey year. Note that this union measure is appropriately designed to identify teacher contracts that are collectively bargained with a school district rather than a contract with other employee unions.

While the above measure is the most sensible alternative in the COG, it has several drawbacks. The first is that it effectively measures whether a district has a collectively bargained contract with the teachers' union, not whether a teachers' union exists. Given the short lag between certification and negotiation of a first contract, however, this discrepancy likely is small.

The second and more serious problem is classification error in the COG union measure. Although the COG-based union measure is designed to reduce potential measurement error by making the definition of unionization relatively strict, there are significant differences between the COG and election certification measures of union status, which suggests that measurement error exists in the former data. Table C1 contains a com- 
Table C1

A Comparison of Union Status from the Census of Governments and the Union Election Certifications by State and Year

\begin{tabular}{|c|c|c|c|c|c|c|}
\hline \multirow{3}{*}{$\begin{array}{l}\text { Election Certi- } \\
\text { fication Union } \\
\text { Measure }\end{array}$} & \multicolumn{6}{|c|}{ Census of Governments Union Measure } \\
\hline & \multicolumn{2}{|c|}{ Iowa } & \multicolumn{2}{|c|}{ Indiana } & \multicolumn{2}{|c|}{ Minnesota } \\
\hline & Union & Nonunion & Union & Nonunion & Union & Nonunion \\
\hline \multicolumn{7}{|l|}{1972 (\%): } \\
\hline Union & .00 & .67 & 3.63 & 1.98 & 53.58 & 17.78 \\
\hline Nonunion & 5.99 & 93.35 & 10.23 & 84.16 & 19.40 & 9.24 \\
\hline \multicolumn{7}{|l|}{1977 (\%): } \\
\hline Union & 49.89 & 14.19 & 57.43 & 22.77 & 55.89 & 20.79 \\
\hline Nonunion & 9.31 & 26.61 & 11.55 & 8.25 & 16.17 & 7.16 \\
\hline \multicolumn{7}{|l|}{1982 (\%): } \\
\hline Union & 51.22 & 17.96 & 55.12 & 26.73 & 58.20 & 22.17 \\
\hline Nonunion & 8.43 & 22.39 & 8.58 & 9.57 & 13.16 & 6.47 \\
\hline \multicolumn{7}{|l|}{1987 (\%): } \\
\hline Union & 46.78 & 25.28 & 42.24 & 40.59 & 64.67 & 16.86 \\
\hline Nonunion & 9.76 & 18.18 & 6.60 & 10.56 & 13.63 & 4.85 \\
\hline No. of districts & & 435 & & 297 & & 431 \\
\hline
\end{tabular}

SOURCE.-Author's calculations from the 1972, 1977, 1982, and 1987 Census of Governments and the teachers' union election certification data, described in the text.

Note.-The number of districts represents the total number of districts in the sample in 1987.

parison of district-level unionization rates from the COG and the election certifications for each state in the sample. I constructed the COG measure by a straightforward implementation of the above definition of unionization. Note that the COG is conducted every 5 years and therefore that labor relations information was only included in the 1972, 1977, 1982, and 1987 surveys.

Table C1 illustrates the substantial differences between the two union measures. In the table, each four-cell square sums to one, and each diagonal within a cell represents the observations for which the union measures agree. For example, in Iowa in 1977, the COG and the election certification measures agree that $49.89 \%$ of school districts were unionized and $26.61 \%$ were not. However, $9.31 \%$ of the school districts are classified as unionized by the COG measure but had not successfully completed a teachers' union election by that date. Conversely, $14.19 \%$ of districts had completed an election but were measured as not unionized by the constructed COG union measure.

I interpret the disagreement between the two data sources as measurement error, with true union status measured by the election certifications. Given that there was little voluntary recognition occurring in these states in this period and that the validation study made every attempt to find such districts, measurement error in the COG is a natural explanation for why there are districts that had not completed a unionization election yet were measured as unionized by the COG. Further, since most districts achieve a contract within a year of certification, the lag between certifi- 
cation and successfully negotiating a contract cannot explain why so many districts that had certified unions were not measured as unionized by the COG.

The accuracy of the COG unionization construct also is called into question by the differential time trends in union status within states across measures. Because there are no decertifications, unionization as measured by election certifications weakly increases over time. Thus, conditional on completing a successful election, a district always will be classified as unionized. In contrast, after 1977, unionization rates decline over time in the COG: while 788 districts were measured as unionized by the COG in 1977, this number fell to 771 districts in 1982 and to 742 districts in 1987. These declines are not consistent with the lack of any evidence of decertification or cessation of collective bargaining in this time period in these three states.

To investigate further the source of the discrepancy, I look at which of the three criteria used in the COG union measure "fail" when a district has completed a successful unionization election but is not classified as unionized in the COG. I find for such districts in all three states the provision that the percentage of teachers who are union members must be greater than 50 fails at higher rates over time. It is likely that this variable constitutes the main source of measurement error in the COG union measure. First, the COG is filled out by district administrators, who may not know how many teachers are union members. ${ }^{35}$ Second, even if the union membership rate were accurately measured, Iowa, Indiana, and Minnesota are agency shop states, meaning that employees are covered by the contract and must pay union dues even when they are not union members. That union membership is reducing over time in these states thus creates measurement error in the COG-based union measure, but this decline in membership, even if accurate, has not translated into changes in collective bargaining status. The problems surrounding the measurement of teacher union membership in the COG are the main source of measurement error in the COG union measure.

Another potential source of measurement error is that an increasing number of districts report having no negotiated contracts over time despite the fact that, conditional on obtaining a first contract, it is rare that the teachers are ever without a negotiated contract with the district. ${ }^{36}$ Some of this discrepancy could be due to the fact that, even if a contract expires, teachers typically continue to work under that contract until a new one

\footnotetext{
${ }^{35}$ As correctly noted by a referee, many school districts will have information on union membership because they deduct union dues from teacher paychecks. However, there is enough year-to-year noise in the data to suggest that at least some school districts are not accurately reporting union membership.

${ }^{36}$ While there are no available credible aggregate statistics on this assertion, lawyers I have spoken to at both the AFT and NEA agree with this generalization.
} 
Table C2

Misclassification Rates in the Census of Governments by State and Year, Treating the Election Certifications as the True Measure of Union Status (Percent)

\begin{tabular}{lrccc}
\hline Year & Iowa & Indiana & Minnesota & Average \\
\hline 1972 & 6.65 & 12.21 & 37.18 & 19.21 \\
1977 & 23.50 & 34.32 & 36.95 & 31.17 \\
1982 & 26.39 & 35.33 & 35.33 & 31.93 \\
1987 & 35.03 & 47.19 & 30.48 & 36.48 \\
\hline
\end{tabular}

Source.-Author's calculations from the 1972, 1977, 1982, and 1987 Census of Governments and the teachers' union election certification data, described in the text.

Note.-The misclassification rate is the sum of the total number of times the Census of Governments and the election certification union measures disagree for each state and year. Each state-level misclassification rate is calculated by taking the sum of the offdiagonal entries from the appropriate four-cell square in table $\mathrm{C} 1$. The average misclassification rate is a weighted average of the state-level misclassification rates, where the weight is the number of school districts in each state and year.

is negotiated with the district. One explanation for the decrease in unionization rates apparent in the COG is that expired contracts are coded as "no contract" despite the fact that negotiated work rules and wage schedules are in place in these districts. These results provide suggestive evidence that the measure of the existence of contracts in the COG contains measurement error. ${ }^{37}$

Taking the election certification data as the true measure of unionization status, table $\mathrm{C} 2$ reports the misclassification rates by state and year in the COG. Aside from 1972, the average misclassification rate remains relatively constant at between $31 \%$ and $36 \%$ in the sample. However, the misclassification rate is as high as $47.2 \%$ in Indiana in 1987. Saltzman (1985) provides some outside validation for these misclassification rates. He validates the 1977 COG union measure for 1,000 districts in the United States and finds a misclassification rate of $30 \%$ for the United States, which is similar to the $31 \%$ misclassification rate I report for my sample of three states in that year.

\section{The Effect of Different Union Measures on Union Impact Estimates}

The high misclassification rates from the union measure constructed from the COG suggest that this measure does not accurately characterize the history and state of collective bargaining in the school districts in the sample. In order to understand more fully the differences between my

${ }^{37}$ Given the errors in the COG labor relations data, one must be skeptical of the accuracy of the financial and employment information in these surveys as well. However, since the survey is filled out by the central administrative offices that have access to payroll records and budgets, it is reasonable to expect that such data will be supplied with greater accuracy than the number of teachers belonging to the union. 
results and those from the existing literature, I undertake a comparison of union impact estimates using the two available district-level union measures. Specifically, I replicate estimates from Hoxby (1996) using both union measures because it is the most comprehensive and empirically sophisticated study of teachers' unions in the literature and because our studies use similar data and time periods.

The empirical specifications in Hoxby (1996) are of the form:

$$
Y_{i t}=\beta_{0}+\beta_{1} U_{i t}+\delta X_{i t}+\tau_{i}+\phi_{t}+\psi_{i}{ }^{*} t+\varepsilon_{i t},
$$

where $Y_{i t}$ is an outcome variable of interest, $U_{i t}$ is an indicator variable equal to one if district $i$ is unionized at time $t, X_{i t}$ is a vector of the demographic characteristics listed in Section II.B in the main text, $\tau_{i}$ are district fixed effects, $\phi_{t}$ are year fixed effects, $\psi_{i}^{*} t$ are district-specific linear time trends, and $\varepsilon_{i t}$ is a normally distributed error term.

Tables C3-C5 present the results of the regressions when $Y_{i t}$ is, alternatively, log real teacher pay, log real current operating expenditures per student, and student-teacher ratios, as these are the dependent variables analyzed by Hoxby. Each regression contains 3 years of data from the 1970, 1980, and 1990 U.S. Census school district files combined with the 1972, 1982, and 1987 COG data, described in Section II.B. Column 1 in tables C3-C5 presents the results taken directly from Hoxby (1996). Column 2 contains estimates using Hoxby's methodology on my sample of three states and allows me to determine how much of the difference in our estimates is due to the fact that I use only three states and she uses all districts in the United States. Column 3 is identical to column 2, except unionization is measured using the election certification data. This last column thus will yield insight into the effect of the measurement error on union impact estimates.

Hoxby identifies union effects by using only within-state variation through the use of district fixed effects and by an instrumental variables (IV) strategy that uses only cross-state variation over time in collective bargaining laws. As I only have data for three states, I am restricted to a within-state analysis. While this restriction is justified by my more accurate union data and the lack of evidence of union threat effects, as discussed in Section III.A, I only will compare my results to the withinstate estimates from Hoxby (1996).

Changing the unionization measure has a large impact on estimates of union effects in all three tables. In table $\mathrm{C} 3$, the union impact estimates on $\log$ real teacher pay using the COG union measure are similar in magnitude, sign, and statistical significance for the national sample and the Midwest sample. However, when I employ the election certification definition of unionization, the coefficient on the union variable becomes negative, smaller in magnitude, and not statistically significant at even the $10 \%$ level. Note that the standard error on the union coefficient increases 
Table C3

Comparison of the Effect of Different Union Measures and Estimation Samples on Estimates of the Union Impact on Teacher Pay

\begin{tabular}{|c|c|c|c|}
\hline \multirow[b]{3}{*}{ Independent Variable } & \multicolumn{3}{|c|}{$\begin{array}{l}\text { Dependent Variable: } \\
\text { Ln (Real Monthly Average Teacher Pay) }\end{array}$} \\
\hline & \multicolumn{2}{|c|}{ COG/Hoxby (1996) } & \multirow{2}{*}{$\begin{array}{c}\text { Election Certification } \\
\text { IA, IN, and } \\
\text { MN Estimation } \\
\text { Sample } \\
(3)\end{array}$} \\
\hline & $\begin{array}{c}\text { U.S. } \\
\text { Estimation } \\
\text { Sample } \\
(1)\end{array}$ & $\begin{array}{l}\text { IA, IN, and } \\
\text { MN Estimation } \\
\text { Sample } \\
(2)\end{array}$ & \\
\hline Union & $\begin{array}{l}.051^{* * *} \\
(.008)\end{array}$ & $\begin{array}{l}.054 * * \\
(.024)\end{array}$ & $\begin{array}{c}-.019 \\
(.072)\end{array}$ \\
\hline Log Population & $\begin{array}{c}-.015 \% * \% \\
(.004)\end{array}$ & $\begin{array}{l}.029 \\
(.063)\end{array}$ & $\begin{array}{l}.029 \\
(.057)\end{array}$ \\
\hline$\%$ Urban & $\begin{array}{l}.0005 * * \\
(.0002)\end{array}$ & $\begin{array}{l}.0004 \\
(.0007)\end{array}$ & $\begin{array}{l}.0003 \\
(.0007)\end{array}$ \\
\hline Log Average income & $\begin{array}{l}.02 \% * \\
.1922)\end{array}$ & $\begin{array}{l}-.066 \\
(.186)\end{array}$ & $\begin{array}{l}-.049 \\
(.187)\end{array}$ \\
\hline Log Median rent & $\begin{array}{c}-.021 * * \\
(.010)\end{array}$ & $\begin{array}{c}.064 \\
(.103)\end{array}$ & $\begin{array}{c}.078 \\
(.107)\end{array}$ \\
\hline$\%$ Below poverty & $\begin{array}{c}-.0001 \\
(.0006)\end{array}$ & $\begin{array}{c}-.009 \\
(.006)\end{array}$ & $\begin{array}{c}-.009 \\
(.007)\end{array}$ \\
\hline \% Unemployed & $\begin{array}{l}-.003 * * \\
(.001)\end{array}$ & $\begin{array}{l}-.009^{*} \\
(.005)\end{array}$ & $\begin{array}{l}-.009 * \\
(.005)\end{array}$ \\
\hline$\%$ Black & $\begin{array}{l}-.004 * \% \\
(.001)\end{array}$ & $\begin{array}{l}.0001 \\
. .010)\end{array}$ & $\begin{array}{l}.002 \\
. .009)\end{array}$ \\
\hline$\%$ Hispanic & $\begin{array}{c}-.004^{* * *} \\
(.001)\end{array}$ & $\begin{array}{c}.002 \\
(.010)\end{array}$ & $\begin{array}{l}.001 \\
(.011)\end{array}$ \\
\hline$\% 12-15$ years school & $\begin{array}{l}-.00 * \\
(.0003)\end{array}$ & $\begin{array}{c}-.002 \\
(.004)\end{array}$ & $\begin{array}{c}-.004 \\
(.004)\end{array}$ \\
\hline$\% 16+$ years school & $\begin{array}{l}.004^{* * *} \\
(.0004)\end{array}$ & $\begin{array}{l}-.005 \\
(.005)\end{array}$ & $\begin{array}{l}-.007 \\
(.005)\end{array}$ \\
\hline$\%$ Private enrollment & $\begin{array}{l}.001 * * \\
(.0002)\end{array}$ & $\begin{array}{l}.003 \\
(.004)\end{array}$ & $\begin{array}{l}.004 \\
(.004)\end{array}$ \\
\hline Log Public school enrollment & $\begin{array}{l}.041^{* * *} \\
(.002)\end{array}$ & $\begin{array}{c}-.050 \\
(.057)\end{array}$ & $\begin{array}{c}-.053 \\
(.057)\end{array}$ \\
\hline$R^{2}$ & NR & .9366 & .9337 \\
\hline \multicolumn{4}{|c|}{$\begin{array}{l}\text { SOURCE.-Estimates in col. } 1 \text { come from Hoxby (1996, table IV, col. 6). Col. } 2 \text { contains estimates using } \\
\text { the COG-based union measure on the IA, IN, and MN sample. Col. } 3 \text { presents estimates using the } \\
\text { election certification union data on the IA, IN, and MN sample. Estimates in cols. } 2 \text { and } 3 \text { are calculated } \\
\text { from the } 1972,1982 \text {, and } 1987 \text { Census of Governments; the } 1970,1980 \text {, and } 1990 \text { U.S. Census; and the } \\
\text { teachers' union election certification data, described in the text. } \\
\text { NoTE.-Hoxby (1996) uses median household income, whereas I use mean household income because } \\
\text { median household income is not included in the } 1970 \text { Census school district summary files. All regressions } \\
\text { include district and year fixed effects as well as district-specific linear time trends. Standard errors are } \\
\text { clustered at the district level and are shown in parentheses. NR = not relevant. } \\
\text { * Significant at the } 10 \% \text { level. } \\
* \text { Significant at the } 5 \% \text { level. }\end{array}$} \\
\hline
\end{tabular}

by a factor of three between columns 2 and 3 in table C3. This increase occurs because there is variation in the COG measure that is due to measurement error and is correlated with the dependent variable (see Sec. C3). Eliminating this variation increases the standard error estimate substantially. While the union estimate in column 3 does not allow one to rule out the verity of the union estimate in column 1 , it illustrates the fragility of the estimate to correcting for measurement error. 
Table C4

Comparison of the Effect of Different Union Measures and Estimation Samples on Estimates of the Union Impact on Current Operating Expenditures per Student

\begin{tabular}{|c|c|c|c|}
\hline \multirow[b]{3}{*}{ Independent Variable } & \multicolumn{3}{|c|}{$\begin{array}{c}\text { Dependent Variable: } \\
\text { Ln (Real Current Operating Expenditure per Student) }\end{array}$} \\
\hline & \multicolumn{2}{|c|}{ COG/Hoxby (1996) } & \multirow{2}{*}{$\begin{array}{c}\text { Election Certification } \\
\text { IA, IN, and } \\
\text { MN Estimation } \\
\text { Sample } \\
(3)\end{array}$} \\
\hline & $\begin{array}{c}\text { U.S. } \\
\text { Estimation } \\
\text { Sample } \\
(1)\end{array}$ & $\begin{array}{c}\text { IA, IN, and } \\
\text { MN Estimation } \\
\text { Sample } \\
(2)\end{array}$ & \\
\hline Union & $\begin{array}{l}.029 * * \\
(.007)\end{array}$ & $\begin{array}{c}.017 \\
(.017)\end{array}$ & $\begin{array}{c}-.010 \\
(.064)\end{array}$ \\
\hline Log Population & $\begin{array}{l}.029 * * \\
(.004)\end{array}$ & $\begin{array}{l}.013 \\
.068)\end{array}$ & $\begin{array}{l}.013 \\
. .068)\end{array}$ \\
\hline$\%$ Urban & $-.001 * \%$ & $\begin{array}{l}-.0004 \\
(.0007)\end{array}$ & $\begin{aligned}-.0004 \\
(.0007)\end{aligned}$ \\
\hline Log Average income & $\begin{array}{l}.116 \% \\
(.019)\end{array}$ & $\begin{array}{l}.146 \\
(.149)\end{array}$ & $\begin{array}{l}.151 \\
(.150)\end{array}$ \\
\hline Log Median rent & $\begin{array}{l}.232 * * \\
(.008)\end{array}$ & $\begin{array}{l}-.032 \\
(.105)\end{array}$ & $\begin{array}{l}-.027 \\
(.106)\end{array}$ \\
\hline$\%$ Below poverty & $\begin{array}{l}-.007 \\
(.001)\end{array}$ & $\begin{array}{l}-.009^{*} \\
(.005)\end{array}$ & $\begin{array}{l}-.009 * \\
(.005)\end{array}$ \\
\hline \% Unemployed & $\begin{array}{l}-.005 * * \\
(.001)\end{array}$ & $\begin{array}{l}-.006 \\
(.004)\end{array}$ & $\begin{array}{l}-.006 \\
(.005)\end{array}$ \\
\hline$\%$ Black & $\begin{array}{l}.005 \% \\
(.001)\end{array}$ & $\begin{array}{c}-.005 \\
(.006)\end{array}$ & $\begin{array}{c}-.004 \\
(.005)\end{array}$ \\
\hline$\%$ Hispanic & $\begin{array}{l}.003^{* * *} \\
(.001)\end{array}$ & $\begin{array}{c}-.005 \\
(.008)\end{array}$ & $\begin{array}{c}-.005^{*} \\
(.009)\end{array}$ \\
\hline$\% 12-15$ years school & $\begin{array}{l}.005 \% * \\
(.001)\end{array}$ & $\begin{array}{r}-.0001 \\
(.003)\end{array}$ & $\begin{array}{c}-.001 \\
(.003)\end{array}$ \\
\hline$\% 16+$ years school & $\begin{array}{l}.004 \% * \\
(.001)\end{array}$ & $\begin{array}{l}-.007 \\
(.005)\end{array}$ & $\begin{array}{l}-.008^{*} \\
(.005)\end{array}$ \\
\hline$\%$ Private enrollment & $\begin{array}{l}.003 \% * \\
(.001)\end{array}$ & $\begin{array}{c}-.001 \\
(.003)\end{array}$ & $\begin{array}{c}-.001 \\
(.003)\end{array}$ \\
\hline Log Public school enrollment & $\begin{array}{l}-.409 * * \\
(.011)\end{array}$ & $\begin{array}{l}-.024 \\
(.031)\end{array}$ & $\begin{array}{l}-.025 \\
(.030)\end{array}$ \\
\hline$R^{2}$ & NR & .9661 & .9660 \\
\hline
\end{tabular}

Source.-Estimates in col. 1 come from Hoxby (1996, table III, col. 6). Col. 2 contains estimates using the COG-based union measure on the IA, IN, and MN sample. Col. 3 presents estimates using the election certification union data on the IA, IN, and MN sample. Estimates in cols. 2 and 3 are calculated from the 1972, 1982, and 1987 Census of Governments; the 1970, 1980, and 1990 U.S. Census; and the teachers' union election certification data, described in the text.

Note.-Hoxby (1996) uses median household income, whereas I use mean household income because median household income is not included in the 1970 Census school district summary files. All regressions include district and year fixed effects as well as district-specific linear time trends. Standard errors are clustered at the district level and are shown in parentheses. NR $=$ not relevant.

* Significant at the $10 \%$ level.

* Significant at the $5 \%$ level.

A similar pattern emerges in table $\mathrm{C} 4$, which presents results for current operating expenditures per student. Switching from the national to the Midwest sample reduces the magnitude of the union coefficient, but the signs are the same across columns 1 and 2. However, in column 3, the union impact estimate becomes negative when I use the election certification measure and the standard error increases by a factor of 3.8. Table 
Table C5

Comparison of the Effect of Different Union Measures and Estimation Samples on Estimates of the Union Impact on Student-Teacher Ratios

\begin{tabular}{|c|c|c|c|}
\hline \multirow[b]{3}{*}{ Independent Variable } & \multicolumn{3}{|c|}{ Dependent Variable: Student-Teacher Ratio } \\
\hline & \multicolumn{2}{|c|}{ COG/Hoxby (1996) } & \multirow{2}{*}{$\begin{array}{c}\text { Election Certification } \\
\text { IA, IN, and } \\
\text { MN Estimation } \\
\text { Sample } \\
(3)\end{array}$} \\
\hline & $\begin{array}{l}\text { U.S. } \\
\text { Estimation } \\
\text { Sample } \\
(1)\end{array}$ & $\begin{array}{l}\text { IA, IN, and } \\
\text { MN Estimation } \\
\text { Sample } \\
\text { (2) }\end{array}$ & \\
\hline Union & $-1.112 * *$ & $\begin{array}{l}.117 \\
(547)\end{array}$ & -.189 \\
\hline Log Population & $-.841 * *$ & 1.154 & 1.158 \\
\hline$\%$ Urban & $\begin{array}{l}(.071) \\
.029 * * \\
(.003)\end{array}$ & $\begin{array}{c}(2.618) \\
.020 \\
(.015)\end{array}$ & $\begin{array}{c}(2.604) \\
.020 \\
(.014)\end{array}$ \\
\hline Log Average income & $\begin{array}{c}-1.170 * * \\
(.367)\end{array}$ & $\begin{array}{c}-4.698 \\
(4.100)\end{array}$ & $\begin{array}{c}-4.660 \\
(4.150)\end{array}$ \\
\hline Log Median rent & $\begin{array}{c}-1.167^{* * *} \\
\quad(.161)\end{array}$ & $\begin{array}{c}.024 \\
(2.519)\end{array}$ & $\begin{array}{c}.056 \\
(2.483)\end{array}$ \\
\hline$\%$ Below poverty & $\begin{array}{c}.149 \\
(.012)\end{array}$ & $\begin{array}{c}-.038 \\
(.136)\end{array}$ & $\begin{array}{c}-.039 \\
(.137)\end{array}$ \\
\hline \% Unemployed & $\begin{array}{l}.123 * \% \\
(.015)\end{array}$ & $\begin{array}{c}-.101 \\
(.103)\end{array}$ & $\begin{array}{c}-.102 \\
(.103)\end{array}$ \\
\hline$\%$ Black & $\begin{array}{c}-.143^{* * *} \\
(.012)\end{array}$ & $\begin{array}{l}.285 \\
(.478)\end{array}$ & $\begin{array}{c}.286 \\
(.455)\end{array}$ \\
\hline$\%$ Hispanic & $\begin{array}{c}-.065^{* *} \\
(.014)\end{array}$ & $\begin{array}{l}-.162 \\
(.233)\end{array}$ & $\begin{array}{c}-.161 \\
(.225)\end{array}$ \\
\hline$\% 12-15$ years school & $\begin{array}{c}-.129 \% * \\
(.011)\end{array}$ & $\begin{array}{c}.071 \\
(.098)\end{array}$ & $\begin{array}{c}.067 \\
(.105)\end{array}$ \\
\hline$\% 16+$ years school & $\begin{array}{l}-.082 \% * \\
(.015)\end{array}$ & $\begin{array}{l}.165 \\
(.154)\end{array}$ & $\begin{array}{l}.162 \\
(.161)\end{array}$ \\
\hline$\%$ Private enrollment & $\begin{array}{c}-.098 \% * \\
(.009)\end{array}$ & $\begin{array}{r}-.250 \\
(.344)\end{array}$ & $\begin{array}{c}-.249 \\
(.345)\end{array}$ \\
\hline Log Public school enrollment & $\begin{array}{l}7.334 * * \\
(.217)\end{array}$ & $\begin{array}{c}-2.990 \\
(4.769)\end{array}$ & $\begin{array}{c}-2.997 \\
(4.745)\end{array}$ \\
\hline$R^{2}$ & NR & .9612 & .9612 \\
\hline
\end{tabular}

Source.-Estimates in col. 1 come from Hoxby (1996, table V, col. 6). Col. 2 contains estimates using the COG-based union measure on the IA, IN, and MN sample. Col. 3 presents estimates using the election certification union data on the IA, IN, and MN sample. Estimates in cols. 2 and 3 are calculated from the 1972, 1982, and 1987 Census of Governments; the 1970, 1980, and 1990 U.S. Census; and the teachers' union election certification data, described in the text.

Note.-Hoxby (1996) uses median household income, whereas I use mean household income because median household income is not included in the 1970 Census school district summary files. All regressions include district and year fixed effects as well as district-specific linear time trends. Standard errors are clustered at the district level and are shown in parentheses. NR $=$ not relevant.

$*$ Significant at the $5 \%$ level.

C5 is more problematic because there is a marked difference between the estimates in the first two columns; the union impact on student-teacher ratios in the three midwestern states is of a different sign than for the nation as a whole. However, the difference in union coefficients and the increase in the size of the standard error of these coefficients between columns 2 and 3 in table $\mathrm{C} 5$ is consistent with the sensitivity of the results reported in Hoxby (1996) to measurement error. ${ }^{38}$

${ }^{38}$ Because the COG union construct measures whether a district has a contract 
The central conclusion from tables C3-C5 is the classification error reported in tables $\mathrm{C} 1$ and $\mathrm{C} 2$ in the COG union measure is not innocuous. My results using the Midwest sample are similar to those in Hoxby (1996) for two of the three comparisons, but switching the union measure illustrates that those results may not be robust to correcting for measurement error. These comparisons underscore the importance of accurately measuring union status in an analysis of teachers' union impacts.

What is most interesting about the form of the measurement error bias is that it is not attenuating, which is the form of bias one would expect from classical measurement error. Classical measurement error occurs when the error is uncorrelated with the dependent variable, the independent variables, the regression error, and the true value of the variable. Despite the fact that the measurement error must be correlated with the true measure of union status as union status is a binary variable, Bound et al. (2001) show that, as long as the misclassification is what Carroll, Ruppert, and Stefanski (1995) term "nondifferential," the bias in the coefficient still will be attenuating as long as the rest of the classical measurement error assumptions hold. I next turn to an examination of the apparent measurement error in the COG union measure in order to reconcile the results in tables $\mathrm{C} 3-\mathrm{C} 5$ with the error in variables suggested by tables $\mathrm{C} 1$ and $\mathrm{C} 2$.

\section{Statistical Properties of the Classification Error}

Table $\mathrm{C} 1$ presents the nonparametric identification of the measurement error in the COG union measure. I now investigate some properties of this classification error and perform a decomposition that breaks the bias due to the error into the part directly due to measurement error and the part due to the correlation of the measurement error with the regression error.

\section{a. Nondifferential Classification Error}

Let $U$ be union status as measured by the COG variables and let $U^{*}$ be true union status as indicated by the election certification data. If $\mu$ is

with a teachers' union and the election certification data measure whether a teachers' union exists for the purpose of collective bargaining, one could argue that the differences between the estimates in cols. 2 and 3 of tables C3-C5 are due to the difference between having a union and having a negotiated contract. As discussed in Sec. II.A of the text, my validation study suggests that most districts achieve a contract within 1 year of certification and no district fails to achieve a contract conditional on certifying a union. While this difference may cause some attenuation in the results, it cannot account for the sign change in coefficient estimates and is likely to be small. 
the measurement error, then

$$
U=U^{*}+\mu .
$$

If one only can observe $U$ instead of $U^{*}$, then instead of estimating the true model given by

$$
Y=\alpha+\beta U^{*}+\delta X+\varepsilon,
$$

one must estimate

$$
Y=\tilde{\alpha}+\tilde{\beta} U+\tilde{\delta} X+\tilde{\varepsilon},
$$

where $\varepsilon$ is the regression error, $X$ is a vector of demographic characteristics assumed to be measured without error, and $Y$ is the outcome variable of interest that contains no measurement error. The standard result under the classical measurement error assumption in which $\mu$ is uncorrelated with $U^{*}, X, Y$, or $\varepsilon$ is that $\tilde{\beta}$ will be less than $\beta$ in absolute value. In other words, classical measurement error will cause an attenuation bias. Note that this result holds regardless of the number of independent variables measured with error as long as the classical measurement error assumptions hold.

When the mismeasured variable is binary, as is the case with union status, the measurement error (i.e., the classification error) cannot be classical. This result is due to the fact $U^{*}$ and $\mu$ will have to be negatively correlated. For example, if $U^{*}=1, \mu \in-1,0$, but if $U^{*}=0, \mu \in 0,1$. Thus, the typical attenuation result does not necessarily hold.

Bound et al. (2001) show that, as long as the misclassification is nondifferential and none of the other classical measurement error assumptions are violated, the bias in the coefficient still will be attenuating. Nondifferential classification error occurs when reporting errors are independent of the dependent variable. More formally, this can be written as follows:

$$
\operatorname{Pr}\left(U=i \mid U^{*}=i, Y\right)=\operatorname{Pr}\left(U=i \mid U^{*}=i\right),
$$

where $i \in 0,1$. I use a linear probability model to test for nondifferential classification error for log real teacher pay, log real current operating expenditures per student, student-teacher ratios, and high school dropout rates. Specifically, I run models of the form

$$
U=\alpha_{0}+\alpha_{1} Y+\eta
$$

where $U$ is an indicator variable that equals ine if the school district is measured as unionized in the COG, $Y$ are the dependent variables used in the analysis in the main text, and $\eta$ is an error term. I perform this test separately for the probability of correctly classifying a district as unionized conditional on being unionized and for the probability of correctly 
Table C6 Tests of Nondifferentiation in the COG Union Measure Classification Error

\begin{tabular}{lcc}
\hline Independent Variable & $\operatorname{Pr}\left(U=1 \mid U^{*}=1, Y\right)$ & $\operatorname{Pr}\left(U=0 \mid U^{*}=0, Y\right)$ \\
\hline Log Real teacher pay & $.356^{* *}$ & -.076 \\
& $(.051)$ & $(.064)$ \\
Log Real expenditures per student & -.002 & $.024 * *$ \\
& $(.015)$ & $(.004)$ \\
Student-teacher ratio & $.017 * *$ & $.007 * *$ \\
& $(.004)$ & $(.002)$ \\
High school dropout rate & -.0003 & $.004 * \%$ \\
& $(.001)$ & $(.001)$
\end{tabular}

NoTE.-Each cell above represents a separate pooled linear probability model regression from the 1972, 1977, 1982, and 1987 Census of Governments and the teachers' union election certification data. Standard errors are in parentheses.

* Significant at the $5 \%$ level.

classifying a district as nonunionized conditional on not being unionized. The estimates of $\alpha_{1}$ test for the existence of differential classification error. These estimates are presented in table C6.

Assuming that the election certification data accurately represent true union status, the data strongly reject that the measurement error from the COG is nondifferential. In each row of table C6, the estimates of $\alpha_{1}$ are statistically different from zero for at least one of the misclassification types. The implication of table $\mathrm{C} 6$ is that the misclassification of union status in the COG is correlated with the dependent variables of interest; the classification error is differential. The bias due to the error in variables therefore is not guaranteed to be attenuating. This result is consistent with the positive biases in absolute value reported in tables C3-C5 of union effects when the imperfectly measured union measure is used.

\section{b. Misclassification as a Function of $\mathrm{X}$}

Thus far, I have established that the intuition about the effect of measurement error on parameter estimates when the error in variables is classical does not hold because $\mu$ is correlated with $Y$ (as the error is differential) and with $U^{*}$ (as the variable is binary). It also is instructive to determine whether the assumption holds that the measurement error is uncorrelated with the observable $X$ 's. To test the relationship between misclassification and the $X$ 's, I estimate the probability that a district is reported as unionized in the COG when it had successfully completed a union election and the probability a district is reported as nonunion in the COG when no union election certification was on file, conditional on observables. More formally, I estimate the following models using a linear probability model:

$$
\begin{aligned}
& \operatorname{Pr}\left(U=1 \mid U^{*}=1, X\right), \\
& \operatorname{Pr}\left(U=0 \mid U^{*}=0, X\right) .
\end{aligned}
$$


Table C7

Relationship between Misclassification in the Census of Government Union Measure and the Observables

\begin{tabular}{|c|c|c|}
\hline Independent Variable & $\operatorname{Pr}\left(U=1 \mid U^{*}=1, X\right)$ & $\operatorname{Pr}\left(U=0 \mid U^{*}=0, X\right)$ \\
\hline Log Population & $\begin{array}{l}.035 \% * \\
(.010)\end{array}$ & $\begin{array}{l}.009 \\
(.013)\end{array}$ \\
\hline$\%$ Urban & $\begin{array}{l}.067 * * \\
(.036)\end{array}$ & $\begin{array}{l}.026 \\
(.041)\end{array}$ \\
\hline Log Average income & $\begin{array}{c}-.007 \\
(.022)\end{array}$ & $\begin{array}{c}-.042 * \% \\
(.007)\end{array}$ \\
\hline Log Median rent & $\begin{array}{c}-.041 \\
(.036)\end{array}$ & $\begin{array}{l}-.126 * * \\
(.024)\end{array}$ \\
\hline$\%$ Poverty & $\begin{array}{c}-.755 * \% \\
(.268)\end{array}$ & $\begin{array}{l}-.570 * \% \\
(.224)\end{array}$ \\
\hline \% Unemployed & $\begin{array}{c}-.002 \% * \\
(.001)\end{array}$ & $\begin{array}{l}-.008 * \% \\
(.001)\end{array}$ \\
\hline$\%$ Black & $\begin{array}{c}-.001 \\
(.003)\end{array}$ & $\begin{array}{l}.022 * \\
(.012)\end{array}$ \\
\hline$\%$ Hispanic & $\begin{array}{l}-.07 \\
(.006)\end{array}$ & $\begin{array}{l}.026 \\
(.020)\end{array}$ \\
\hline$\% 12-15$ years school & $\begin{array}{c}-.001 \\
(.001)\end{array}$ & $\begin{array}{l}.008^{* * *} \\
(.002)\end{array}$ \\
\hline$\% 16+$ years school & $\begin{array}{l}.001 \\
(.001)\end{array}$ & $\begin{array}{c}-.010 * * \\
(.002)\end{array}$ \\
\hline$\%$ Private enrollment & $\begin{array}{l}.004 * \% \\
(.001)\end{array}$ & $\begin{array}{c}-.003^{* * *} \\
(.001)\end{array}$ \\
\hline Log Public school enrollment & $\begin{array}{l}.039 * \% \\
(.010)\end{array}$ & $\begin{array}{l}.010 \\
(.013)\end{array}$ \\
\hline
\end{tabular}

SOURCE.-Author's calculations from the 1972, 1982, and 1987 Census of Governments; the 1970, 1980 , and 1990 U.S. Census; and the teachers' union election certification data, described in the text. Note.-Each cell above represents a separate pooled linear probability model regression. Standard errors are in parentheses.

$*$ Significant at the $5 \%$ level.

Table C7 contains the results from these regressions from the pooled 1970, 1980, and 1990 U.S. Census and COG data described in the main text. Each cell in the table represents a separate regression. As table C7 illustrates, the probability of misclassifying a district's union status is correlated with the observable demographic characteristics of the district. Some general trends do emerge from table C7: smaller, less urban districts with lower public school enrollment are less likely to be correctly classified as unionized, while those districts with lower average income, lower median rent, and a smaller proportion of BA recipients are more likely to be misclassified as unionized. School districts with a higher percentage of residents with 12 or more years of schooling are less likely to be classified as unionized regardless of true union status, and conversely, districts with a higher percentage of private enrollment have a higher probability of being classified as unionized regardless of true union status. Finally, those districts with higher poverty and unemployment rates have a higher probability of being misclassified conditional on their true union status. The assumption necessary for classical measurement error that the error is independent of the correctly measured observables clearly does not hold in the data. 


\section{c. BBDR Decompositions}

Since the misclassification error is correlated with both the dependent variables and the independent variables in the union impact regressions, it is interesting to determine the extent to which each of these correlations cause the observed differences in the estimated union effects. Bound et al. (1994) propose a decomposition of the difference between the biased coefficient and the unbiased coefficient into the difference directly due to measurement error and the difference due to the correlation of the measurement error with the regression error (Bound-Brown-DuncanRodgers [BBDR] decomposition). ${ }^{39}$ More formally, let

$$
Z=[U \mid X]^{\prime}
$$

be a matrix of all the data. Then

$$
\begin{aligned}
\tilde{\beta} & =\left(Z^{\prime} Z\right)^{-1} Z^{\prime} Y \\
& =\left(Z^{\prime} Z\right)^{-1} Z^{\prime}\left[Z^{*} \beta+\varepsilon\right] \\
& =\left(Z^{\prime} Z\right)^{-1} Z^{\prime}[(Z-\mu) \beta+\varepsilon] \\
& =\left(Z^{\prime} Z\right)^{-1} Z^{\prime} Z \beta+\left(Z^{\prime} Z\right)^{-1} Z^{\prime}[-\mu \beta+\varepsilon] \\
& =\beta-\left(Z^{\prime} Z\right)^{-1} Z^{\prime} \mu \beta+\left(Z^{\prime} Z\right)^{-1} Z^{\prime} \varepsilon
\end{aligned}
$$

$$
\Leftrightarrow
$$

$$
\begin{aligned}
\tilde{\beta}-\beta= & -\left(Z^{\prime} Z\right)^{-1} Z^{\prime} \mu \beta+\left(Z^{\prime} Z\right)^{-1} Z^{\prime} \varepsilon \\
=- & (E[\mu \mid U=1, X]-E[\mu \mid U=0, X]) \beta+(E[\varepsilon \mid U=1, X] \\
& -E[\varepsilon \mid U=0, X]),
\end{aligned}
$$

where the last line follows from the fact only union status is assumed to be measured with error in the data. The first term on the right-hand side of equation (C11) gives the part of the total difference that is due to measurement error, while the second term shows the part of the total difference that is due to the correlation between the measurement error and the regression error. I perform this decomposition separately for each of the four dependent variables used above in a model that includes district fixed effects, year fixed effects, and district-specific linear time trends. The coefficient estimates are thus identical to those reported in tables C3-C5.

Table C8 presents the results of the BBDR decompositions. As is evident from the table, both forms of bias are present. These biases reinforce

${ }^{39}$ See Black, Sanders, and Taylor (2003) for an implementation of the BBDR decomposition similar to the one presented here. 
Table C8

BBDR Decompositions

\begin{tabular}{lccccc}
\hline & & & & & \\
Dependent Variable & $\begin{array}{c}\text { COG } \\
\text { Estimate }\end{array}$ & $\begin{array}{c}\text { Enion } \\
\text { Estimate }\end{array}$ & $\begin{array}{c}\text { Total } \\
\text { Difference } \\
\text { from } \\
\text { Measurement } \\
\text { Error }\end{array}$ & $\begin{array}{c}\text { Difference } \\
\text { from Correlation } \\
\text { of Measurement } \\
\text { Error and } \\
\text { Regression Error }\end{array}$ \\
\hline $\begin{array}{l}\text { Log Real teacher pay } \\
\text { Log Real expendi- }\end{array}$ & .054 & -.019 & .073 & .018 & .054 \\
$\begin{array}{l}\text { tures per student } \\
\text { Hident-teacher ratio }\end{array}$ & .017 & -.010 & .027 & .010 & .017 \\
$\begin{array}{l}\text { High school dropout } \\
\text { rate }\end{array}$ & .589 & -.189 & .306 & .183 & .124 \\
\hline
\end{tabular}

Source.-Author's calculations from the 1972, 1982, and 1987 Census of Governments; the 1970, 1980, and 1990 U.S. Census; and the teachers' union election certification data, described in the text.

NoтE.-Each regression includes district and year fixed effects as well as district-specific linear time trends.

each other for log real teacher pay, log real current operating expenditures per student, and student-teacher ratios in this sample. The bias due to measurement error implies that the direct effect of wrongly classifying a district as unionized is to increase the estimated union effect on teacher pay, expenditures per student, and student-teacher ratios. This result occurs because nonunionized districts have higher pay, expenditures, and class sizes than unionized districts, so misclassifying nonunionized districts as unionized will bias upward the estimated impact of teachers' unions on all three measures. That the classification error is positively correlated with the regression error for the three inputs is due to the fact that school districts incorrectly classified as unionized tend to have higher levels of teacher pay, expenditures, and student-teacher ratios than school districts for which union classification is correct. Thus, the misclassification of union status will serve to bias further upward the union impact estimates on these variables.

For the high school dropout rate decompositions, the biases offset each other somewhat, but the relatively large negative effect from measurement error dominates the positive correlation between the measurement error and the regression error. Nonunion schools tend to have lower dropout rates than union schools, which is partially offset by the fact that districts wrongly classified as unionized have higher dropout rates.

\section{References}

Balfour, Alan G. 1974. More evidence that unions do not achieve higher salaries for teachers. Journal of Collective Negotiations 3, no. 4:289-303.

Baugh, William H., and Joe A. Stone. 1982. Teachers, unions, and wages in the 1970's: Unionism now pays. Industrial and Labor Relations Review 35, no. 3:368-76.

Black, Dan, Seth Sanders, and Lowell Taylor. 2003. Measurement of 
higher education in the Census and Current Population Survey. Journal of the American Statistical Association 98 (September): 545-54.

Black, Sandra E. 1999. Do better schools matter? Parental valuation of elementary education. Quarterly Journal of Economics 114, no. 2: 577-99.

Bound, John, Charles Brown, Greg J. Duncan, and Willard L. Rodgers. 1994. Evidence on the validity of cross-sectional and longitudinal labor market data. Journal of Labor Economics 12, no. 3:345-68.

Bound, John, Charles Brown, and Nancy Mathiowetz. 2001. Measurement error in survey data. In Handbook of econometrics, vol. 5, ed. James J. Heckman and Edward E. Leamer. Amsterdam: Elsevier Science.

Brasington, David M. 1999. Which measures of school quality does the housing market value? Journal of Real Estate Research 18, no. 3: 395-414.

Carroll, Raymond J., David Ruppert, and Leonard A. Stefanski. 1995. Measurement error in nonlinear models. Boca Raton, FL: Chapman \& Hall/CRC.

Chubb, John E., and Terry M. Moe. 1988. Politics, markets and the organization of public schools. American Political Science Review 82, no. 4:1065-87.

Courant, Paul N., Edward M. Gramlich, and Daniel L. Rubinfeld. 1979. Public employee market power and the level of government spending. American Economic Review 69, no. 5:806-17.

Dinardo, John, and David S. Lee. 2004. Economic impacts of new unionization on private sector employers, 1984-2001. Quarterly Journal of Economics 119, no. 4:1384-1441.

Eberts, Randall W., and Joe A. Stone. 1986. Teacher unions and the cost of public education. Economic Inquiry 24, no. 4:631-43.

- 1987. Teacher unions and the productivity of public schools. Industrial and Labor Relations Review 40, no. 3:354-63.

Farber, Henry S. 2003. Nonunion wage rates and the threat of unionization. Working Paper no. 472 (March), Industrial Relations Section, Princeton University.

Freeman, Richard B. 1981. The effect of unionism on fringe benefits. Industrial and Labor Relations Review 34, no. 4:489-509.

- 1986. Unionism comes to the public sector. Journal of Economic Literature 24, no. 1:41-86.

Freeman, Richard B., and Morris M. Kleiner. 1990. The impact of new unionization on wages and working conditions. Journal of Labor Economics 8, no. 1, suppl. (January): S8-S25.

Freeman, Richard B., and Robert G. Valletta. 1988. Appendix B: The NBER public sector collective bargaining law data set. In When public sector workers unionize, ed. Richard Freeman and Casey Ichniowski. Chicago: University of Chicago Press. 
Gunderson, Morley. 2005. Two faces of union voice in the public sector. Journal of Labor Research 26, no. 3:393-413.

Haar, Charlene K. 1996. Teacher's unions. American Enterprise 7, no. 5: 35-37.

Hoxby, Caroline Minter. 1996. How teachers' unions affect education production. Quarterly Journal of Economics 111, no. 3:671-718.

Ichniowski, Casey, Richard B. Freeman, and Harrison Lauer. 1989. Collective bargaining laws, threat effects, and the determination of police compensation. Journal of Labor Economics 7, no. 2:191-209.

Johnson, Susan M. 2004. Paralysis or possibility: What do teacher unions and collective bargaining bring? In Teacher unions and education policy: Retrenchment or reform? ed. Ronald D. Henderson, Wayne J. Urban, and Paul Wolman. Amsterdam: Elsevier Science.

Kahn, Lawrence M. 1980. Union spillover effects on organized labor markets. Journal of Human Resources 15, no. 1:87-98.

Kahn, Lawrence M., and Michael Curme. 1987. Unions and non-union wage dispersion. Review of Economics and Statistics 69, no. 4:600-607.

Kleiner, Morris M., and Daniel Petree. 1988. Unionism and licensing of public school teachers: Impact on wages and educational output. In When public sector workers unionize, ed. Richard Freeman and Casey Ichniowski. Chicago: University of Chicago Press.

Lee, David, and Alexandre Mas. 2008. Long-run impacts of unions on firms: New evidence from financial markets, 1961-1999. Working Paper no. 14709, National Bureau of Economic Research, Cambridge, MA.

Moe, Terry M. 2001. A union by any other name. Education Next 1, no. 3:40-45.

Moore, William J., and John Raisian. 1987. Union-nonunion wage differentials in the public administration, educational, and private sectors, 1970-1983. Review of Economics and Statistics 69, no. 4:608-16.

Murphy, Marjorie. 1990. Blackboard unions: The AFT and the NEA, 1900-1980. Ithaca, NY: Cornell University Press.

Neumark, David, and Michael L. Wachter. 1995. Union effects on nonunion wages: Evidence from panel data on industries and cities. Industrial and Labor Relations Review 49, no. 1:20-38.

Retsinas, Joan. 1982. Teachers: Bargaining for control. American Education Research Journal 19, no. 3:353-72.

Saltzman, Gregory M. 1985. Bargaining laws as a cause and consequence of the growth of teacher unionism. Industrial and Labor Relations Review 38, no. 3:335-51.

Smith, Alan W. 1972. Have collective negotiations increased teachers' salaries? Phi Delta Kappan 54, no. 4:268-70.

Tiebout, Charles M. 1956. A pure theory of local expenditures. Journal of Political Economy 64, no. 5:416-24.

U.S. Department of Commerce, Bureau of the Census. 1970. Census of 
Population and Housing [United States]: Fifth-count tallies, sample data for school districts (computer file). ICPSR version. Washington, DC: U.S. Department of Commerce, Bureau of the Census (producer), 1970. Ann Arbor, MI: Inter-university Consortium for Political and Social Research (distributor), 2003.

1980. Census of Population and Housing: Summary tape file 3F: School district, technical documentation. Washington, DC: U.S. Department of Commerce, Bureau of Census (producer and distributor), 1982.

U.S. Department of Education, National Center for Education Statistics. 1970. User's manual for 1970 census fourth count (population): School district data tape (computer file]). ICPSR version. Washington, DC: U.S. Department of Education, National Center for Education Statistics (producer), 1970. Ann Arbor, MI: Inter-university Consortium for Political and Social Research (distributor), 2004.

Woodbury, Stephen A. 1985. The scope of bargaining and bargaining outcomes in the public schools. Industrial and Labor Relations Review 38, no. 2:195-210.

Zuelke, Dennis C., and Lloyd E. Frohreich. 1977. The impact of comprehensive collective negotiations on teachers' salaries: Some evidence from Wisconsin. Journal of Collective Negotiations 6, no. 1:81-88. 